\title{
DIASPORIC IDENTITY AND POLITICAL ACTION: PALESTINIAN STUDENT ACTIVISM ON ONTARIO UNIVERSITY CAMPUSES
}

\author{
by
}

By Laura Ashfield, Honours BA, Wilfrid Laurier University, 2009

\author{
A Major Research Paper \\ presented to Ryerson University \\ In partial fulfillment of the requirements for the degree of \\ Masters of Arts \\ in the Program of \\ Immigration and Settlement Studies
}

Toronto, Ontario, Canada, 2012

(C) Laura Ashfield 2012 


\section{AUTHOR'S DECLARATION FOR ELECTRONIC SUBMISSION OF A MAJOR RESEARCH PAPER (MRP)}

I hereby declare that I am the sole author of this Major Research Paper. This is a true copy of the MRP, including any required final revisions, as accepted by my examiners.

I authorize Ryerson University to lend this MRP to other institutions or individuals for the purpose of scholarly research

I further authorize Ryerson University to reproduce this MRP by photocopying or by other means, in total or in part, at the request of other institutions or individuals for the purpose of scholarly research.

I understand that my MRP may be made electronically available to the public.

Laura Ashfield 


\title{
DIASPORIC IDENTITY AND POLITICAL ACTION: \\ PALESTINIAN STUDENT ACTIVISM ON ONTARIO UNIVERSITY CAMPUSES \\ Laura Ashfield \\ Master of Arts, 2012 \\ Immigration and Settlement Studies \\ Ryerson University
}

\begin{abstract}
This study focuses on how young Palestinians in the diaspora understand their identity, and whether this understanding, as well external perceptions of identity, shape their political actions in terms of solidarity movements with Palestine on Ontario campuses. Eight Palestinian activists (aged 19-32) were interviewed about their perceptions of identity and experiences of activism. The findings suggest that the participants have a strong Palestinian identity maintained by their connections to home and their involvement in Palestinian activism. The participants' engagement with activism reinforced their Palestinian identity, pointing to the interconnected relationship between identity and political action. When examining the experiences of activism on campus, participants garnered support but also faced challenges from pro-Israel groups and university administrations. The implications of these findings are significant to political and academic freedom in Canada and will hopefully encourage universities to foster nondiscriminatory political debate and ensure that all voices are heard.
\end{abstract}

Key Words:

Palestine; identity; diaspora; activism; academic freedom 


\section{ACKNOWLEDGEMENTS}

First of all I would like to thank the eight participants who generously volunteered their time to enable this research study. Their participation is greatly appreciated and their insights have contributed to a growing awareness of Palestinian diasporic identity and the issues of Palestinian solidarity activism on campus.

A big thank you to my supervisor Anver Saloojee for helping and encouraging me each step of the way and providing me with detailed feedback so quickly.

I would like to thank Mary-Jo Nadeau for graciously meeting with me in my early stages of this project to answer my questions, offer support and provide me with valuable resources.

I would also like to thank my second reader Alan Sears for his insightful comments and words of support during my dissertation. I am very glad to have had Alan as my second reader as he is extremely knowledgeable on the subject. Mary-Jo Nadeau and Alan Sears have both paved the way in terms of literature on this topic with their comprehensive articles on the silencing campaign on campus and I am very grateful to have found such compelling and relevant literature to support my project.

I'd also like to acknowledge the people in my life who have supported me by making sure I remained well balanced during this lengthy and intense process. To my mom, Dave, Hannah and my roommate Jenn who also provided her professional editing skills.

Lastly, thanks to my fellow classmates in the Immigration and Settlement Program. I'm glad to have gone through this program with you all. 


\section{TABLE OF CONTENTS}

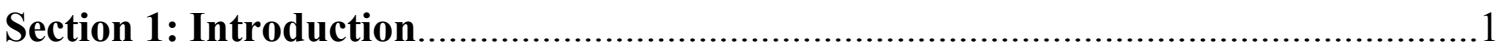

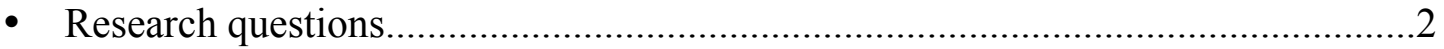

- Summary of findings.......................................................................................

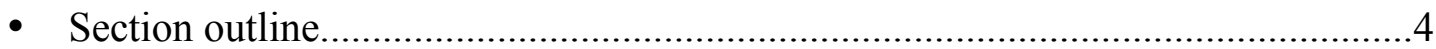

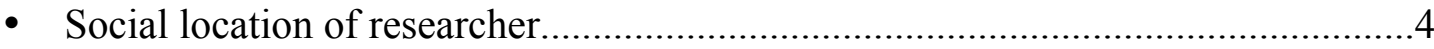

- Conceptual frameworks...................................................................................

Section 2: Literature review: Identity Construction..............................................10

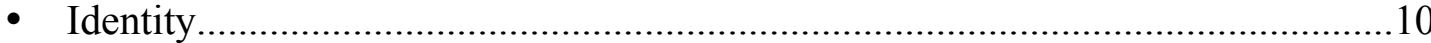

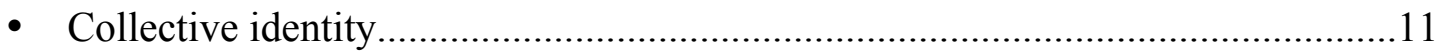

- National identity ..........................................................................................12

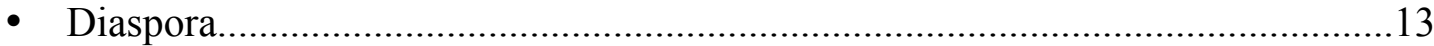

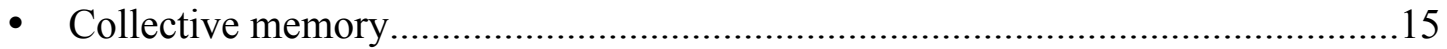

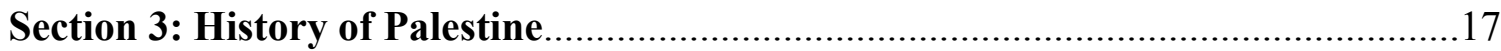

- Palestine before the Nakba..................................................................................17

- Zionism and European Colonialism in Palestine....................................................17

- 1948: The Nakba and the creation of Israel............................................................19

- Occupation of Palestine and Israeli Apartheid.........................................................20

- Resistance and the First and Second Intifadas............................................................23

Section 4: Literature Review: Major Markers of Palestinian Diasporic Identity.....26

- Sub-Section 1: Palestinian Identities..................................................................26

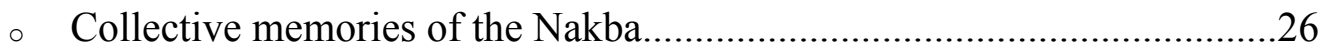

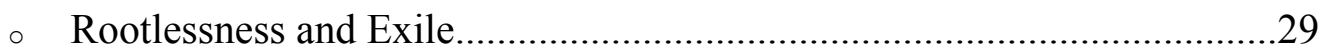

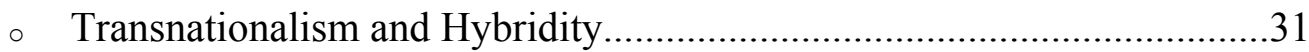

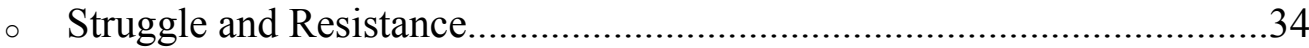

- Sub-Section 2: Palestinian solidarity activism on campus........................................34

- Accusations of Palestinian solidarity activism as anti-Semetic..................37

- Palestinian activism as 'uncivil' and 'threatening'....................................39

- Securitization of Palestinian voices and academic freedom........................40

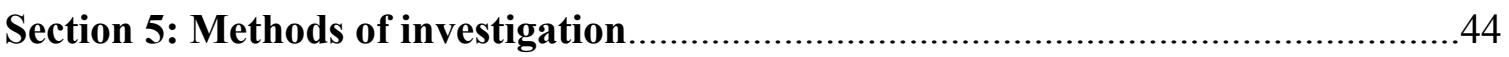

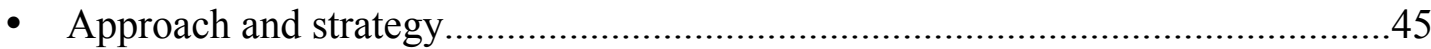

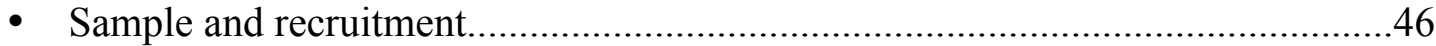

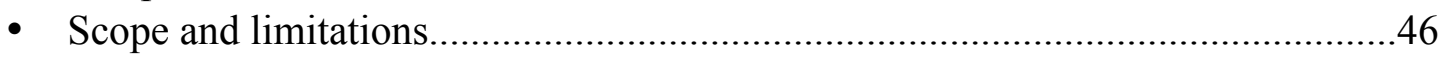

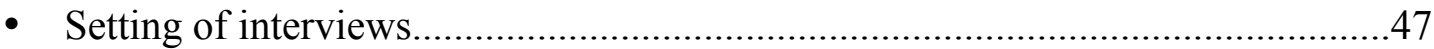

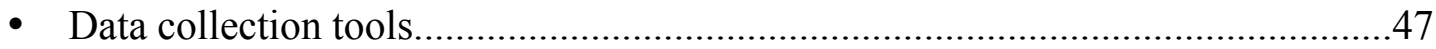

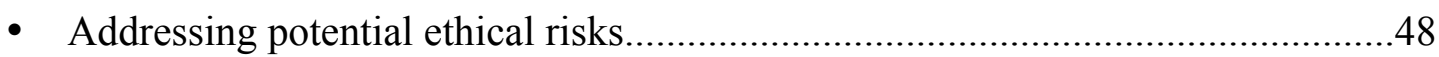

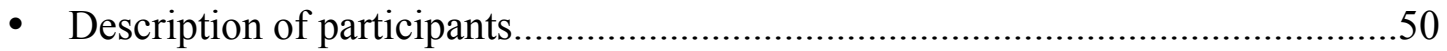




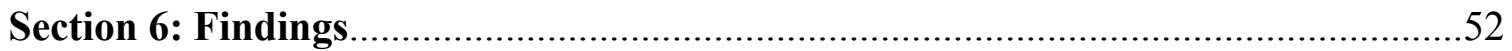

- Section 1: national identity.........................................................................52

- Section 2: transnationalism and the connection to home........................................56

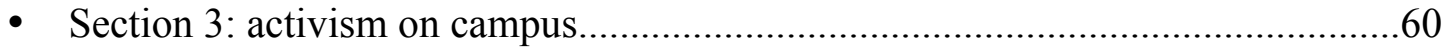

- Section 4: the relationship between identity and political action.............................65

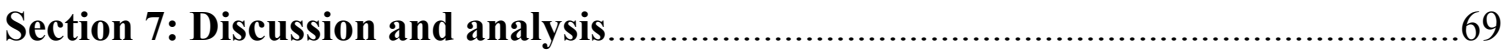

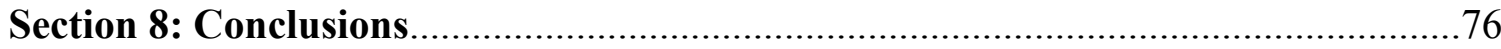

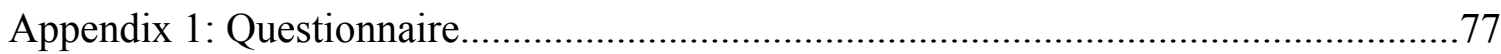

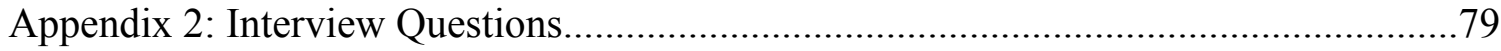

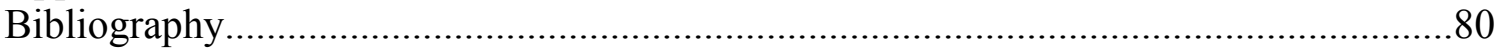

\section{List of Tables and Figures}

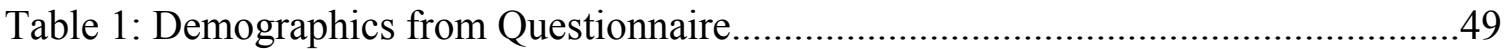

Table 2: Negative and Positive Reactions to Campus Activism........................................62

Figure 1: The Palestinian loss of land from 1946-2000...................................................20

Figure 2.1: The interconnected relationship between identity and political action...........68

Figure 2.2: The interconnected relationship between identity, political action and

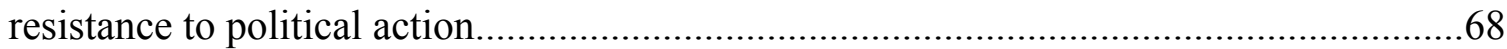

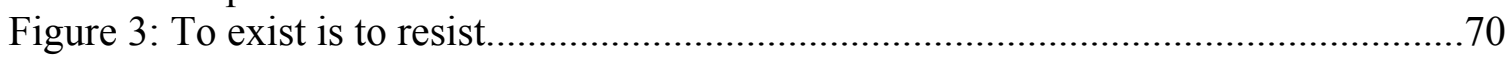




\section{Section 1:}

\section{Introduction}

This MRP will focus on how young Palestinians in the diaspora understand their identity, and whether this understanding, as well external perceptions of identity, shape their political actions in terms of solidarity movements with Palestine on Ontario campuses. The question is two-fold: first, how does a Palestinian-Canadian identity impact the political action of a Palestinian-Canadian university student and how do their political actions in turn impact their identity formation and reformation? The second part relates to how those political actions are then perceived by other students, student groups and the university administration on campuses in Ontario. And it relates to how their identities are further affected by potential resistance to Palestinian solidarity actions on Ontario campuses.

Homelands and the ongoing relationships that immigrants have towards them are central to the study of immigration and settlement (Abdelhady, 2008). Examining diasporic communities can help us understand the maintenance of these ties among immigrant populations in receiving countries such as Canada (Abdelhady, 2008). In addition, the exploration of the identities of diasporic communities could potentially allow Canada and other receiving countries to better understand how it can facilitate immigrant integration and promote social cohesion. This paper will focus on the Palestinian diasporic community in Canada.

The Palestinian diaspora is one of the largest groups of stateless persons anywhere, with five million Palestinians living in the diaspora today, three million of them as refugees (Mason, 2007; Bowker, 2003). Most of these Palestinians live in the 
West Bank, Gaza, Jordan, Syria and Lebanon, but many others live in the diaspora in other Arab or Western countries. The Palestinian diaspora was the result of the ZionistPalestinian conflict and the creation of the state of Israel in 1948. That year, about 750,000 Palestinians were uprooted from their homes and fled to neighbouring Arab countries and other parts of the world (Aoudé, 2001).

Identity, argues Hall (2006, 250), only becomes an issue when it is in crisis, and that is certainly true for the Palestinian population, whose national existence and identity have been in crisis since 1948. Recently, campus events like Israeli Apartheid Week have been demonized and settlement agencies like Palestine House in Mississauga, accused of being 'anti-Semetic', have been defunded by the Government of Canada. There is a common trend of 'othering' Palestinian immigrants in Canada, and more research should be focusing on this particular population in order to better understand the intricacies and complexities of the Palestinian diaspora.

\section{Research Questions}

The focus of this research is on how young Palestinians in the diaspora understand their identity, and whether this understanding, as well external perceptions of identity, shape their political actions in terms of solidarity movements with Palestine on Ontario campuses. The question is two-fold: first, how does a Palestinian-Canadian identity impact the political actions of a Palestinian-Canadian university student and how do these political actions in turn impact their identity formation and reformation. The second part relates to how those political actions are then perceived by other students, student groups and the university administration on campuses in Ontario. And it relates 
to how their identities are further affected by potential resistance to Palestinian solidarity actions on Ontario campuses.

The data gathered will be used to find the relationship between Palestinian identity in the diaspora and political action on campuses. The hypothesis being tested proposes that a stronger affinity to a Palestinian identity leads to political action on campus. My speculation is also that many Palestinian student activists have felt threatened or 'othered' on their campus because of their political actions and identity.

\section{Summary of Findings}

One of the findings in the study worthy of mention is that all eight participants demonstrated a strong Palestinian identity, whether or not they had been to Palestine and whether or not they or their parents were born in Palestine. For most of the participants involved, Palestine is a place of belonging invoking feelings of home, whereas Canada is a place that provides a good education and an escape from reality. In addition, the Second Intifada was very significant for the participants and many recognized the Intifada as instigating their involvement with activism and for helping them become more aware of the issues surrounding Palestine. Five participants mentioned that another reason for their involvement in activism is to raise awareness about the Palestinian issue on campus. Three participants also said that their Palestinian heritage motivates them to be involved in Palestinian solidarity activism.

The student activists interviewed in the study experienced negative and positive reactions from others on campus. Some of the negative reactions include opposition from pro-Zionist/Israeli groups, administration control and student apathy. Positive reactions mentioned were support from individual professors and solidarity with other student 
groups. Overall, this paper will argue that a strong Palestinian identity motivates Palestinian solidarity activism on campus while at the same time, Palestinian activists face challenges on campus from other students and the administration. Both their participation in activism and the resistance that they face reinforces their Palestinian identity.

\section{Section Outline}

This research paper begins with an exploration of the terms identity, collective identity, national identity and diaspora by including differing authors' perspectives on the theories of identity construction in section 2 . Section 3 will provide a brief history of Palestine in order to contextualize the experiences of Palestinians in the diaspora. Section 4 focuses on different themes of identity found throughout the literature on the Palestinian diaspora. Section 5 will discuss the methodology of the research process. It will describe how the data was collected and explain the scope and limitations of the research study, while also providing a description of the participants involved. The findings of the study will be laid out in section 6 , pointing out key themes and patterns in participants' responses during interviews. The analysis section of the MRP, section 7, will incorporate pre-existing literature and conceptual frameworks to analyze and comprehend the data. Lastly, I will conclude the paper with my personal reflections in section 8 .

\section{The Social Location of the Researcher}

While it is important to clearly articulate one's position and previous knowledge of or experience with the topic, it is equally important to note that I am not Palestinian and therefore cannot relate to Palestinian identities or experiences. Nonetheless I am deeply 
concerned about social justice in Palestine and Israel. This social location and concern with issues related to Palestine have a bearing on the selection of this topic for the MRP.

I have travelled to Israel/Palestine a number of times and have attended conferences concerning the conflict. The first time I went, in 1989 during the First Intifada (Palestinian uprising), I was three years old. My parents were studying at an ecumenical college in Bethlehem in the West Bank and some of my first memories took place in Palestine. The second time I went was in the summer of 2008 when I attended the Sabeel Young Adult Conference, educating international youth about the occupation of Palestine. During the conference, we visited refugee camps, met with Israeli and Palestinian non-governmental organizations working for peace, volunteered with various projects and listened to the stories of the people we met. In January 2010, I travelled to Egypt for the Gaza Freedom March with Code Pink (a women's peace organization), commemorating the one-year anniversary of the bombings in Gaza. After that, I then went to Israel/Palestine again to meet with organizations and visit friends. My experiences in Palestine have deeply affected me and I have been profoundly changed by the people that I met there.

Since coming home from my trip in 2008, I have been involved with Palestinian solidarity activism on and off campus. On campuses, I connected with the Students for Palestinian Rights at University of Waterloo and Laurier 4 Palestine at Wilfrid Laurier University, and was greatly inspired by the dedication and passion that the Palestinian and non-Palestinian students showed in organizing solidarity events around KitchenerWaterloo. While participating in events with these Palestinian solidarity groups, there was much controversy and tension with other groups on campus, particularly Israel on 
Campus (IOC) and the Jewish Students Associations (JSA). These groups, it seemed, would come to events to intimidate and silence Palestinian voices. I experienced this first-hand when I spoke about my first trip at the Wilfrid Laurier University campus. About eight students from Israel on Campus came to hear me speak and instead of engaging in debate, they were aggressive in nature and attempted to silence and discredit me. I have a personal bias, as everyone does, and I am extremely passionate about this topic. My previous experiences in Israel/Palestine and my participation in activism in Canada have both shaped my conceptual framework on issues pertaining to the Palestinian diaspora.

\section{Conceptual Framework}

There are two theoretical frameworks that I will use in the analysis section of the paper, the first being Manuel Castells' concept of 'resistance identity', and the second being Edward Said's 'orientalism'. Manual Castells' writings on identity will provide me with a theoretical understanding of the concept of 'resistance identity'. Castells $(2004,7)$ says that identities are people's sources of meaning and experiences and that they are constructed through a process of individuation. Although identities can be formed by dominant institutions, (i.e. national identities), they become identities only when and if an individual internalizes them (Castells, 2004, 7).

Castells $(2004,8)$ outlines three forms of identity building. The first one is 'legitimizing identity', which is used by dominant institutions to justify their power (Castells, 2004, 8). The second, which will be used in the analysis of this paper, is 'resistance identity', which is built by groups of people who are stigmatized and oppressed by dominant groups (Castells, 2004, 8). Thus, building 'identities of 
resistance' oppose the dominant group in society and act as a survival mechanism. The third is 'project identity' in which individuals or groups build a new identity that redefines their position in society, seeking structural change in society at large (Castells, 2004, 8).

'Resistance identity', Castells (2004) argues, leads to the formation of communities and may be the most important type of identity formation in our society. "It constructs forms of collective resistance against otherwise unbearable oppression, usually on the basis of identities that were, apparently, clearly defined by history, geography, or biology, making it easier to essentialize the boundaries of resistance" (Castells, 2004, 9). For example, ethnically based nationalism (i.e. Palestinian nationalism) arises out of a sense of exclusion, alienation and resentment of the unjust treatment (Castells, 2004, 9). Castells (2004) calls this process "the exclusion of the excluders by the excluded". That is, the building of defensive and resistant identities in opposition to dominant oppressive powers. Aouragh $(2011,12)$ reiterates this point by arguing that national identity is particularly strong in non-state 'contested' groups and that as Palestinians are one of the largest and longest lasting stateless and exiled communities in the world, they strongly hold on to their national identity. Eid $(2007,32)$ calls this phenomenon 'reactive ethnicity', which he defines as a defensive ethnic consciousness in response to ethnicbased prejudice, discrimination and exclusion. He says that groups that have been stigmatized have the ability to turn negative stereotypes and attitudes into a badge of pride or honor. This theory helps in analyzing Palestinian diasporic identities as 'resistance identity.' 
Secondly, when researching the Palestinian diaspora, which has undergone exile and has suffered and continues to suffer great injustices, it is essential to work through the theoretical lens of Edward Said's concept of orientalism. Said (2007, 45), a Palestinian, asserts that orientalism is a discourse of repressions framed by a set of political forces that brought the Orient into Western consciousness and empire. Orientalist theory relies on binary oppositions: the Orient (the East) is opposite to the Occident (West) (Said, 1978). The Oriental is seen as irrational, immoral, or childlike, and 'different'; thus the European is rational, virtuous, mature, and 'normal' (Said, 1978). Orientals, then, were not analyzed as citizens or people, but as problems to be solved, confined or taken over by colonial powers (Said, 2007, 47). They were thought to be gullible, cunning, dishonest or lethargic, in opposition to the clarity, directness and nobility of the Anglo-Saxon race (Said, 1978, 38-39). Jensen (2011) defines 'othering' as a process by which powerful groups "define subordinate groups into existence in a reductionist way which ascribe problematic and/or inferior characteristics to these subordinate groups." Those who become 'the other' are usually individuals who are subject to colonialism by the powerful (Jenson, 2011).

In Said's book, Orientalism, (1978) as well as The Question of Palestine (1979), he uses his theory of orientalism to explain some of the common attitudes about Palestine. Edward Said argues that because of orientalism, Palestinians' struggle for freedom is ignored and the occupation of Palestine is justified (Said, 1978). He says that there should be no doubt that the conflict in the Middle East stems from an advanced European Jewish culture colonizing a more traditional Muslim or Christian Arab culture (Said, 1979, 8). Because the Palestinian population was seen as inferior, or as 'oriental', 
Zionist and colonial powers felt entitled to their land. Said's theory of orientalism serves as a framework with which to view the treatment of Palestinian activists on campuses in Canada. Without acknowledging the power dynamic that orientalism describes and the historical and current perceptions of the Palestinian people, the analysis in this paper would be incomplete. 


\section{Section 2:}

\section{Literature Review: Identity Construction}

This section begins with an exploration of the terms identity, collective identity, collective memory, national identity, and diaspora, which will be used throughout this paper. All of these terms are relevant in the identity formation of Palestinian students in Canada and will provide a general understanding of how identity is formed.

\section{Identity}

The term identity has recently been a significant subject of study and discussion, inside and outside of the academic world (Gilroy, 2006, 117). Identity can mean an individual's personal view of himself or herself, which situates and defines the individual (Rockquemore, 2006, 148). Social characteristics like gender, race, ethnicity, ability, age and sexual orientation can influence a person's attitudes, personality and motivations and can contribute to their identity formation, along with factors like citizenship status, political affiliation, family and education (James, 2006, 43).

Identity can be conceived in many different ways. Cultural theorist and sociologist Stuart Hall $(2006,250)$, identifies three very different concepts of identity: the first being the Enlightenment model, the second being the sociological concept and the third being the postmodern theory. The Enlightenment era theorizes identity as the center of an individual, which remains essentially the same throughout their life (Hall, 2006, 250). For these 'essentialists,' identity is fixed, ascribed and innate, much like eye colour or skin tone (Bramadat, 2001). The sociological perspective on the other hand, says that identity is formed in the 'interaction' between self and society. Individuals still have an inner core that defines the individual, but this is formed in a "continuous dialogue with 
the cultural worlds 'outside' and the identities that they offer" (Hall, 2006, 250). In other words, identity bridges the gap between the personal and the public worlds and is the direct result of mutual identification through social interaction (Rockquemore, 2006, 148). Lastly, postmodernism affirms that identity is not permanent, static or set. According to Hall $(2006,250)$, postmodern subjects assume different identities at different stages in their life. These identities are never stagnant, but can constantly change and adapt to new circumstances and can overlap and intersect. In addition, each personal identity can mean different things to each person and can vary by favorability, importance, meaning and attachment (Coleman \& Lowe, 2007).

\section{Collective Identity}

Collective identities, in contrast to individual identities, refer to a shared and widespread view of a particular group of people who may think, "I am who I am because I am a member of this group" (Coleman \& Lowe, 2007). Coleman and Lowe (2007) in their study on collective identities of Palestinian and Israeli diasporas say that every individual can hold multiple collective identities, which can be overlapping or conflicting in nature. Collective identities are a set of assumptions regarding how a group defines itself and are human constructions that are influenced by communal narratives about the history and nature of a group (Bramadat, 2001).

Emile Durkheim emphasized group identity over individual identity when he introduced the concept of 'collective consciousness' as the primary architect of identity (Allahar, 2006, 33). He talks about similarities as creating social solidarity, which is what leads members of groups to "love their country...to like one another, seeking one another out in preference to foreigners (Allahar, 2006, 33). 
Eid $(2007,23)$ points to internal boundaries and external boundaries that work together to construct collective identity. He says that internal boundaries are the "shared memory and history that provide ethnic groups with the symbolic material it needs for the construction of its collective self or "us"' (Eid, 2007, 23). On the other hand, the external boundaries of collective identity are made up of the ethnic group's self image, which is defined by the majority group or 'them' (Eid, 2007, 23). Ethnicity, a type of collective identity based on race and nationhood, gives individuals a sense of identity based on their perceptions of being different but also on the knowledge that they are perceived by others as being different (James, 2006, 48).

\section{National Identity}

Another form of collective identity is national identity. A nation is not just a political entity, but it also produces a system of cultural representation (Hall, 2006). As Benedict Anderson has argued (as cited in Hall, 2006, 254), national identity is an 'imagined community'. These 'imagined communities' are constructed by producing meanings (i.e. stories, memories, symbols and images) about the nation with which individuals can identify (Hall, 2006, 254). This is done through national histories, literature, media and popular culture. National identities, along with collective and individual identities are a production, which Eid $(2007,20)$ says is never complete and always in the process of changing. This dynamic process is increased by globalization and migration patterns, which create hybrid or hyphenated national identities, like ItalianCanadian, Scottish-American or Palestinian-Australian.

For Gilroy $(2006,118)$, national identity also becomes a question of power when a group seeks to recognize itself in political form. Sometimes the concept of national 
identity can become a "struggle for recognition" in a world with dominant oppressive powers, and recognition of national identity becomes the principal goal of political mobilization (Fraser, 2006, 234). National identity can be a powerful form of identity formation for groups and individuals. Hall $(2006,253)$ points out that when defining ourselves we tend to say what country we are from or which country we were born into. We think of our national identities as part of our fundamental selves (Hall, 2006, 253).

\section{Diaspora}

Diasporas are an interpersonal network, characteristically produced by forced dispersal and reluctant scattering (Gilroy, 2006, 124). According to Vijay Agnew (2005, 193) in the book, Diaspora, Memory, and Identity: A Search for Home, the word 'diaspora' refers to the dispersion of a group of people from one center or two or more peripheral places. Agnew $(2005,193)$ says that diaspora also refers to the collective memory and trauma involved in such dispersion. The origin of the word 'diaspora' comes from the Greek verb Speiro, meaning 'to sow', and dia, meaning 'over', suggesting networks of real or imagined relationships between scattered peoples, whose sense of community is kept up by transnational communication (Agnew, 2005, 192). Diasporas are usually communities that have been unwillingly dispersed by slavery, genocide, war, expulsion, indentured labour, political exile or refugee exodus (Agnew, 2005, 193). Therefore, push factors are a dominant influence for diasporas as the groups have usually fled from threats of violence or oppression (Gilroy, 2006, 124).

The classical definition of diaspora includes, along with exile, an inability to return home and constant longing for home (Kalra et al., 2005, 10). Therefore according to Kalra et al $(2005,11)$, diaspora first means to be from one place but of another. The 
notion of home for those in a diaspora is complex. Hamid Naficy (as cited in Abdelhady, 2008) explains that "home is anyplace; it is temporary and it is moveable; it can be built, rebuilt, and carried in memory by acts of imagination". For Peteet (2007), the key issue for diasporas is the tie to the homeland. Diaspora includes "dispersal from an original homeland, a collective memory of the homeland, a belief that one cannot be fully accepted into the host society, a desire for return and restoration of the homeland, and maintaining ties to the homeland" (Peteet, 2007). In fact, diasporas are even said to create notions of homeland, rather than the other way around. "Rather than conceiving of the homeland as something that creates the diaspora, it may be more productive to consider the diaspora as something that creates the homeland" (Peteet, 2007).

Abdelhady (2008) in her study, Representing the Homeland: Lebanese Diasporic Notions of Home and Return in a Global Context, explains that the notion of temporary homes defy traditional ideas of belonging and identity. According to Gilroy $(2006,123)$, diaspora turns the notion that territory determines identity upside down, by "breaking the simple sequence of explanatory links between place, location, and consciousness". Similarly, Kalra et al. $(2005,32)$ point to the concept of diaspora as challenging the nation by debunking the idea that land and cultural association are natural sources of identification. Diasporas rely upon the idea of a homeland rather than a homeland being grounded in the actual territory (Kalra et al., 2005, 32). To frame it metaphorically, "diaspora disturbs the suggestion that political and cultural identity might be understood via the analogy of indistinguishable peas lodged in the protective pods of closed kinship and subspecies being" (Gilroy, 2006, 124). 
In the book Being Arab: Ethnic and Religious Identity Building among Second

Generation Youth in Montreal, Eid (2007) uses the term symbolic ethnicity to describe his participants' identity formation. According to Eid $(2007,29)$, "symbolic ethnicity is a lingering ethnic self-concept largely cut off from the cultural and social environment that would normally sustain and reinforce it." Therefore, symbolic ethnicity exists by individuals maintaining their ethnic identity while separated from the rest of the ethnic community through the diaspora. Eid $(2007,28)$ found that although members of the second generation have become largely socialized in the host society and have grown more familiar with the dominant culture than with their own ethnic cultural background, they persisted in identifying strongly with their ethnic group and culture.

\section{Collective Memory}

'Collective memories' are memories of a shared past retained by many people, including multiple generations (Agnew, 2005, 200). Agnew $(2005,200)$ says that they can be found in oral or written stories, rumours, or institutionalized cultural activities. Collective memories therefore do not have to be personally experienced. Rather, they are the shared knowledge of past events that have been passed on from generation to generation. Collective memory consists of nostalgic feelings and memories inherited from family, and can be equally as powerful as lived experiences (Peteet, 2007). Michel Foucault reminds us that collective memory is also fundamentally political and is a very important factor for struggling populations (Agnew, 2005, 200). Memory can also contribute to identity formation and the idea of home and of belonging for exiled people, diasporas and immigrants (Agnew, 2005, 200). 
Each of these terms and theories help build an understanding of how identity is formed and changed. For Palestinian youth in the diaspora, their understanding of their identity is shaped by their individual, collective, national and diasporic identities. Being part of a diasporic community can affect their ideas of themselves, as they may see themselves as both Canadian and Palestinian, creating a hybrid identity. Having a grasp of the literature on different forms of identity formation will provide the context to the study of Palestinian identities in Canada. 


\section{Section 3:}

\section{History of Palestine}

This section will provide a very brief history of Palestine, highlighting the creation of Israel in 1948 and the occupation that Palestinians live under today. It provides the context in which Palestinians in Palestine and the diaspora understand their identity and carry out resistance.

\section{Palestine before the Nakba}

Except for very brief periods of time, the Ottoman Empire ruled Palestine from 1517 to the end of The First World War (Qumsiyah, 2011, 36). Under Ottoman rule in the nineteenth century, Palestine had over 672 villages and towns with a population of over 460,000, most of which were peasants, with some Bedouins and city dwellers (Qumsiyah, 2011, 37). From 1800 to 1948, Farsoun \& Zacharia $(1997,21)$ argue the history of Palestine can be summarized in one phrase: European interventionism.

\section{Zionism and European Colonialism in Palestine}

The colonization of Palestine was part of the European political and economic program that sought to explore, conquer, settle and exploit large parts of the 'Oriental' world (Al-Rimmawa, 2009). In Palestine, this type of racism and imperialism is called Zionism (the belief that Jews alone have the right to the land). Zionists did not even recognize that Palestinians existed when they coined the term, "A land without people for a people without land" when in fact there were approximately nine million Palestinians living there (Al-Rimmawa, 2009). The Zionist mission was clear: Westerners must dominate Orientals, occupy their land, control their people, and take their resources (AlRimmawa, 2009). 
In the early $20^{\text {th }}$ Century, the British Empire was in the process of colonizing Palestine for a Jewish homeland. In 1917 the British Government wrote the infamous Balfour Declaration in the form of a letter to Lord Rothschild (who represented Zionist interests), encouraging the "establishment in Palestine of a national home for the Jewish people" (Said, 1979, 18). This declaration was inherently orientalist: it was written by a European power about a non-European territory in frank disregard for the presence of the natives to the land (Said, 1979, 15-16). Both the British imperialist and the Zionist are united in playing down and canceling out the Arabs in Palestine as secondary and insignificant (Said, 1979, 18). Palestine was seen as a place to possess and reconstruct for a more deserving and capable power: the European Jewish population (Said, 1979, 9).

How then did Israel as a country come into existence? The creation of The World Zionist Organization in 1897 started the systematic establishment of Jewish settlements in Palestine in hopes to garner future public recognition of a legally secured Jewish homeland (Al-Rimmawa, 2009). Theodore Herzl was the main advocate for this Zionist organization and stressed Palestine as the 'promised land' for Jews. After the support of Britain with the Balfour Declaration and the commencement of colonial British mandate Palestine, Jews began to settle in large numbers in Palestine (Al-Rimmawa, 2009). Between 1919 and 1931, 82,000 Jewish immigrants arrived in Palestine (Al-Rimmawa, 2009). The rise of the Nazi movement in Germany in the 1930s and 1940s intensified Jewish immigration to the Middle East and after the Holocaust and the Second World War there was a push for an internationally recognized Jewish state in Palestine (AlRimmawa, 2009). 


\section{8: The Nakba and Creation of Israel}

After the declaration by the UN of the establishment of Israel in 1948, the expulsion of around one million Palestinians by Zionists took place in order to facilitate the reconstruction of Palestine and the creation of Israel (Al-Rimmawa, 2009). Palestinian refugees fled or were forced to the areas now known as The West Bank and Gaza Strip. Most refugees still live in refugee camps established by the United Nations in Syria, Lebanon, Jordan, the Gaza Strip and the West Bank, located within a hundred miles or so of their former homes in Israel (Peteet, 2007). Palestine was considered a desert that the Zionists would irrigate and cultivate until it became the blooming garden that it once was (White, 2009, 16). This can be taken literally, but also symbolically: the desert represents the Palestinian population, unable to cultivate the land; the blooming garden represents the Jewish population, capable and hard working. Uri Davis $(2003,61)$, in his book, Apartheid Israel: Possibilities for the Struggle Within, says that declaring the State of Israel a 'Jewish State' reflected the core ideologies of political Zionism, namely, a state for Jews throughout the world, purposefully excluding Muslim and Christian Arabs. According to Israeli law, only a Jewish citizen has full civic rights and privileges, whereas Arabs are given simpler, more restrictive rights (Said, 1978, 306). Ben White (2009) builds on this theory in his book, Israeli Apartheid: A Beginner's Guide. He says that a racist, exclusionary view of the Arab natives was unavoidable, because of the fact that the Zionist goal was to create a purely Jewish state in Palestine. This orientalist way of thinking, can only lead to the development of a racist state of mind (White, 2009, 16). The borders of the state of Israel were deliberately left undefined in 1948 in the hopes that its borders and control would further expand, which they did (David, 2003, 61). In 
1967, Israel attacked the West Bank and Gaza Strip creating a new wave of Palestinian refugees, and after the 1967 war Israel launched settlement projects within the West Bank and Gaza Strip, further controlling Palestinian lands (Al-Rimmawa, 2009). It is clear that the Zionist project and the creation of the state of Israel relied upon orientalist perspectives in order to subordinate the already existing native Palestinian population. The next section will focus on present day occupation and resistance in Palestine.

\section{Figure 1: The Palestinian loss of land from 1946-2000}

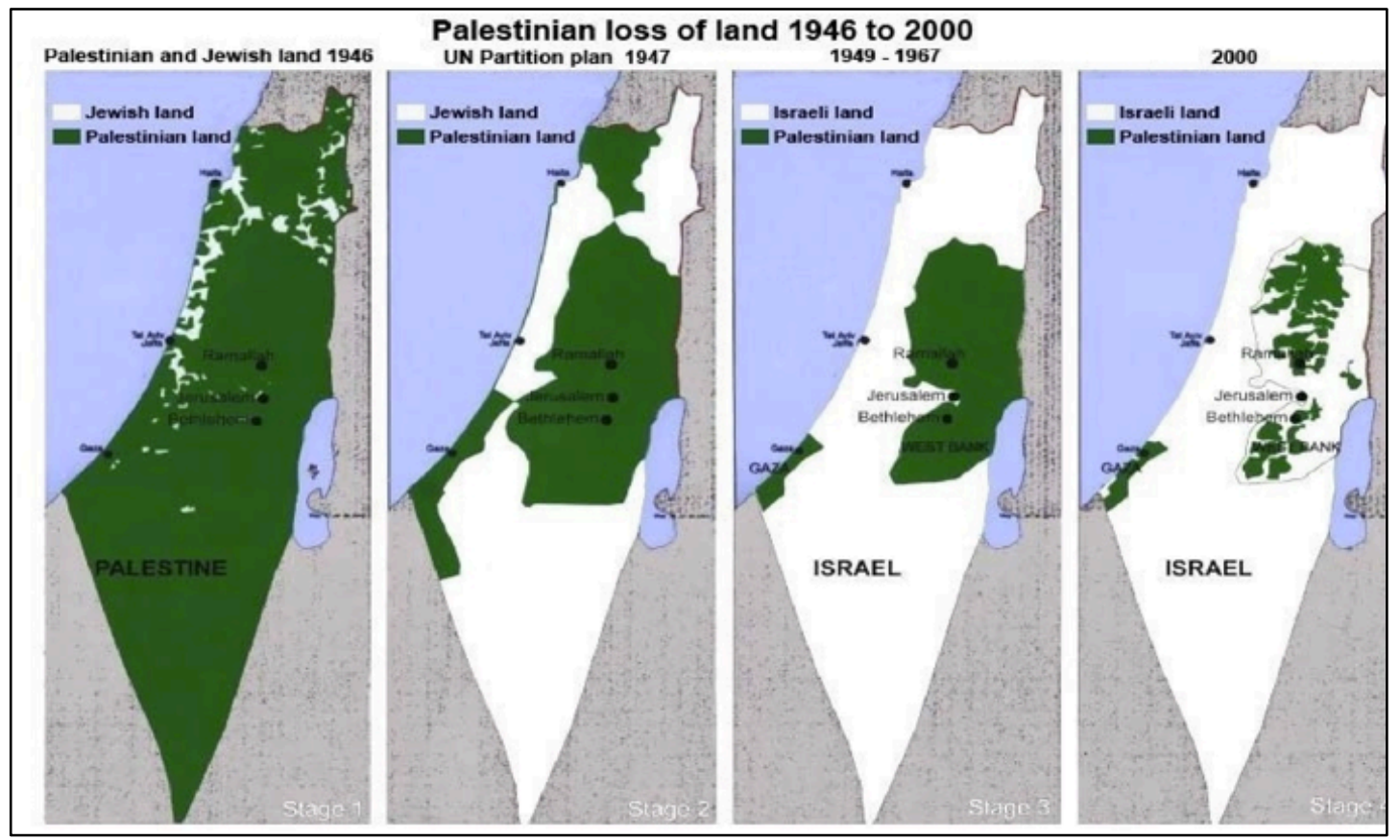

Image: http://lawrenceofcyberia.blogs.com/photos/maps/landloss.html

\section{Israeli Apartheid and the Occupation of Palestine}

The birth of the nation of Israel was a colonial endeavor. It is still very much a settler colonial country, but now also a state that occupies another nation and controls it under an apartheid system. It is established on ethnic, national and religious separation (Hasan, 2008). Many supporters of Israel take offence when the word apartheid is associated with Israel, claiming that it is a democratic state that treats all of its citizens 
equally. But when actually looking at the definition of apartheid, Israel falls under the definition for a multitude of reasons. The UN General Assembly met in 1973 for the International Convention on the Suppression and Punishment of the Crime of Apartheid and agreed on a general definition of apartheid, which is as follows:

For the purpose of the present Convention, the term 'the crime of apartheid', which shall include similar policies and practices of racial segregation and discrimination as practiced in Southern Africa, shall apply to the following inhuman acts committed for the purpose of establishing and maintaining domination by one racial group of person over any other racial group of person and systematically oppressing them.

Resolution 3068, 30 November 1973 (White, 2009, 3)

One of the 'inhuman acts' that the UN went on to list, which apply to the situation in Israel, is the "denial of members of a racial group the right to life and liberty of person". Others worth noting are "any legislative measures calculated to prevent a racial group from participating in the political, social, economic and cultural life of the country", "the right to leave and to return to their country", the "right to a nationality" and the "right to freedom of movement and residence" (White, 2009, 4). Apartheid, while based on racial discrimination, is not just the presence of racism; it is also a political system in which racism is regulated through laws and policies (Davis, 2003, 37). Therefore apartheid, as defined by the UN, includes any legislative measures designed to divide a nation's population by race by creating separate reserves and ghettos for members of a certain racial group (White, 2009, 4). So, how does this play out in terms of Palestinians' daily lives? 
In the article Spacio-cide: colonial politics, invisibility and rezoning in Palestinian territory, Sari Hanafi (2009) coins the term 'spacio-cidal' (as opposed to genocidal) to describe the Israeli colonial project. She argues that Israel targets land for the purpose of encouraging the 'voluntary' movement of the Palestinian population. She says that the systematic destruction of the Palestinian living space becomes possible by 'dividing and conquering' to keep the population powerless (Hanafi, 2009). The spaciocide of Palestine is done through four major forces: the military, the building of Israeli settlements in the West Bank, urban planners and capitalist real-estate speculators (Hanafi, 2009). These forces work together along with government policies to encourage the emigration of the Palestinian population by making their lived space impossible to live in (Hanafi 2009).

Israeli peace activist Jeff Halper (2009), in his book Obstacles to Peace, identifies what he calls Israel's 'Matrix of Control,' which represents the Zionist doctrine that tries to dominate and subordinate the Arab population so intensely and overwhelmingly that they will despair ever having a viable state of their own. The 'Matrix of Control' is a complex system of law, military orders, bureaucratic structures, procedural limitations on movement, settlements and infrastructure that serve to occupy the Palestinian population, but at the same time conceal the occupation by routinizing Israeli control behind the façade of 'proper administration' (Halper, 2009). The occupation of Palestine is realized by Israeli settlements, the 'security' or separation wall, checkpoints, separate highway systems and house demolitions, all making life in Palestine extremely difficult. 


\section{Resistance and the First and Second Intifadas}

Said $(1979,8)$ argues that Palestinian identity is firmly rooted in the act of resistance to foreign Israeli colonialism. There is a web of racism, cultural stereotypes, political imperialism and dehumanizing ideology that is working against the Palestinian identity, and every Palestinian has come to feel the heavy weight of injustices hanging over their heads (Said, 1978, 27). Since 1948, Palestinians have been preoccupied in the problems of everyday life with little time left for organizing, planning and acting against their oppressors (Said, 2002, 245). However, at the same time many Palestinians are engaged in resistance to the occupation. Palestinians, along with their international supporters, are fighting against Israeli apartheid through protests, boycotts, peace organizations, education programs and other forms of activism.

The most well known acts of defiance against Israeli oppression in Palestine are known as the Intifadas (meaning 'shaking off' in Arabic). In the autumn of 1987 a number of demonstrations against Israeli occupation initiated the First Intifada from 1987 to 1991, which became known as the "Uprising of the stones" (Intifadet Al-Hajara), as youth responded to Israeli brutality by throwing stones at Israeli soldiers and tanks (Qumsiyah, 2011, 134-135). The uprising developed spontaneously and spread throughout Palestine through stages of ad hoc protests, organized calls, demonstrations, boycotts and establishing Palestinian leadership to replace the occupation authority (Qumsiyah, 2011, 138). The First Intifada also signified a revival of Palestinian nationalism through the use of Palestinian flags, art, cooking and culture (Qumsiyah, 2011, 152). However, the Palestinian population faced an intense crackdown from Israeli forces and in the first two years of the uprising, Israeli forces and settlers had killed 824 
Palestinian civilians, injured over 80,000, arrested more than 50,000 and demolished 1225 homes (by contrast, eight Israeli soldiers and three settlers were killed) (Qumsiyah, 2011, 153).

The Second Intifada started in 2000 after anger and frustration from Israeli policies in the 1990s and the flawed Oslo peace process. The Oslo Accord, an attempt at peace talks spearheaded by the United States, was viewed by many Palestinians as yet another form of occupation, while most Israelis felt that it had failed to protect their personal safety (Pappe, 2006, 272). In the summer of 2000, Palestinians grew frustrated and rose in reaction to what they considered a humiliating offer made by American President Clinton and Israeli Prime Minister Barak (Palestinian leaders were asked to forsake the main reason for their struggle since 1948: the right of return of the refugees expelled by Israel in 1948) (Pappe, 2006, 276). However, the trigger that set off the new uprising was when Israeli politician, Ariel Sharon visited the holy Muslim site of Al-Aqsa in September of 2000 surrounded by 1,000 armed Israelis (Qumsiyah, 2011, 169).

Palestinians held a peaceful demonstration the next day, which was suppressed by Israeli soldier brutality, leaving six Palestinian civilians dead (Qumsiyah, 2011, 169). Again protests were met with intense violence. One million bullets were fired in the first two weeks of the Second Intifada with the intent of ensuring the uprising would end quickly and effectively (Qumsiyah, 2011, 169). In 2002, the Israeli government started building the separation wall, isolating Palestinians from their lands, schools, workplaces, hospitals and families (Qumsiyah, 2011, 177). The resistance to the atrocious wall started strongly and continued strongly with the help of Palestinian grassroots organizations and international solidarity movements (Qumsiyah, 2011, 177). Resistance against Israeli 
occupation continues daily in Palestine and throughout the diaspora by Palestinians and international citizens in solidarity.

This section has provided a short history of Palestine and given a context to understand Palestinian diasporic identities as well as Palestinian solidarity activism on campuses. Comprehending the history and the current realities in Palestine is crucial when studying Palestinian solidarity activism in order to understand the reasons behind political action. 


\section{Section 4:}

\section{Major Markers of Palestinian Diasporic Identity}

This section presents a selective review of literature on Palestinian identities from 2001 to 2007 . In order to find relevant literature on this subject, I used the Ryerson University Library and Archives database and Google Scholar. Words that I used in the search engines were a combination of Palestine, Palestinians, diaspora, immigrant, identity, transnational and resistance. For this literature review, a combination of scholarly journal articles and books on the topic were used. Some of the on-line journals included Conflict Resolution Quarterly, Israel Studies, Journal of Intercultural Studies, and Asian Studies Review. The first sub-section of this literature review will concentrate on notions of Palestinian identity, with four main themes. The second section will focus on resistance and activism, with three themes, focusing on the negative reactions to resistance, specifically on Ontario campuses.

\section{Sub-Section 1: Palestinian Identities}

Four themes have been identified in the literature on Palestinian diasporic identity. First, the importance of collective memories of the Nakba to Palestinian identity will be explored. Second, the theme of rootlessness and exile will follow. Third, transnationalism and hybridity will be discussed with the last theme focusing on the notions of struggle and resistance in Palestinian identities.

Theme 1: Collective Memories of the Nakba (catastrophe). When reviewing the literature on Palestinian identity and experiences, a central theme that came up was the importance of the Nakba to Palestinian collective memory. Juliane Hammer (2005), 
Robert Bowker (2003), Victoria Mason (2007) and Ahmad H. Sa'di (2002) all point to the events of 1948 as a defining point in Palestinian history and identity.

As mentioned earlier, the Nakba means catastrophe in Arabic and can be described as the event when Palestinian life changed forever. When Zionist forces entered Palestine and the UN announced the birth of the state of Israel in 1948, between $77 \%$ and $83 \%$ of the Palestinians who lived in the area became refugees (Sa'di, 2002). Therefore, the Nakba represents the loss of homeland, the breakup of their society and the beginning processes of the destruction of their culture (Sa'di, 2002).

In Bowker's book about Palestinian refugees $(2003,96)$, he argues that more than any other single factor, the collective memory of the Nakba in 1948 has shaped the identity of the Palestinian refugees as a people and has sustained political energy for over five decades. He points to the commemorative Nakba Day, which is observed every $15^{\text {th }}$ of May since 1998 throughout the West Bank, Gaza Strip, refugee camps in other Arab countries and in diaspora communities around the world, as an indication that the 1948 tragedy is deeply etched into the Palestinian historical narrative (Bowker, 2003, 95-96).

The book Palestinians Born in Exile: Diaspora and the Search for a Homeland, by Juliane Hammer (2005) focuses on Palestinians who were born in other countries in the diaspora. She draws attention to the connection between memory and identity, and how the shared trauma of 1948 reinforced pre-existing elements of identity while strengthening a Palestinian self-definition that was already present (Hammer, 2005, 35). Hammer $(2005,35)$ believes that the consequences of 1948 brought Palestinians together in terms of their collective memory, even though they were physically dispersed all over the world. Also, the Nakba destroyed the traditional social structure of Palestinian 
society, disconnecting the rural farming population from the land. Therefore, the land and the desire for Palestinians to return to it became a 'national' symbol (Hammer, 2005, 35).

The paper Children of the "Idea of Palestine": Negotiating Identity, Belonging and Home in the Palestinian Diaspora by Victoria Mason (2007) explores how the maintenance of Palestinian identity and attachment to the homeland has remained crucial to the generation that experienced the Nakba, the first generation born into exile, and the second generation born into exile. This article uses Palestinians from Kuwait who immigrated to Australia as a result of the 1990/91 Gulf conflict as a case study in order to investigate the ideas of homeland within the Palestinian diaspora (Mason, 2007). Mason (2007) explains that immediately after the Nakba in 1948, most Palestinians believed that their exile was temporary and that they would soon return to their homeland. Therefore, in the beginning, many Palestinian refugees refused to create permanent roots in their host country. However, as decades went by with no hope of returning home to Palestine, Palestinians in the diaspora had to maintain their national identity while living in another country (Mason, 2007). In order to do this, Palestinian experiences have been transmitted to new generations through relaying details and stories about the homeland by parents, grandparents and extended family (Mason, 2007).

One of the most compelling pieces of literature on the theme of the Nakba was Ahmad H. Sa'di's article, Catastrophe, Memory, and Identity: Al-Nakbah as a Component of Palestinian Identity. This article was mostly a review of other works about Palestine and the Nakba, including poetry by the famous Palestinian poet Mahmoud Darwish, quotes from Edward Said and segments from Palestinian historian, Elias Sanbar. Sa'di (2002) reiterates that the Nakba connects all Palestinians to a specific point 
in time, which has become what he calls, an 'eternal present'. He talks of major efforts to reconstruct the past, such as books and photograph collections, which attempt to preserve what Palestine was like before the Nakba (Sa'di, 2002). Since the catastrophe is a major site of Palestinian collective memory, many Palestinians began to use the Nakba as a temporal reference point, saying that an event took place, for example, one year after the Nakba or three years before (Sa'di, 2002). He notes that the Nakba represents an end to normality, which manifests itself on individuals in three ways: obsession with the past, constant speculative questioning ('what would have happened if...?'), and a struggle to return to normality (Sa'di, 2002). The Nakba was the moment when the Palestinian people became homeless, rootless and a people in exile.

Theme 2: Rootlessness and Exile: a 'wandering' population. Along with the Nakba, notions of homelessness and rootlessness are also common themes in the literature. Palestinians are often described as a 'wandering' and 'mobile' population searching for a lost home (Schulz \& Hammer, 2003, 86). Palestinian stories are framed by journeys from one place to another, as families are scattered across the globe (Schulz \& Hammer, 2003, 87). Schulz and Hammer $(2003,88)$ in their book The Palestinian Diaspora: Formations of Identities and Politics of Homeland argue, then, that the condition of being Palestinian is to move and that the quintessential Palestinian experience takes place at borders, checkpoints, and airports where identities are checked and verified. At these spots of world travel, Palestinians are constantly reminded that Palestine is not an official country and that they have no home of their own. Palestinians themselves have used the Arabic term 'ghurba' meaning estrangement from home to 
signify their situation, emphasizing injustice, loss and suffering (Schulz \& Hammer, 2003, 93).

While in exile, the state of mind of the exiled is transformed. Edward Said writes about his state of homelessness with a deep sense of insecurity and describes his habit of over-packing for even short trips, using this as an example of how homelessness has become a part of the consciousness of exiled Palestinians (Sa'di, 2002). Being exiled from your home creates a state of liminality, limbo and confusion and generates a feeling of not really being a part of the world (Schulz \& Hammer, 2003, 94). Schulz and Hammer $(2003,97)$ go as far to say that it was not in the rootedness and peasant past that Palestinians gained a particular form of Palestinian-ness, but that it was only after they were forced out of their homes that Palestinians found their unique identity and contemporary meaning.

The authors also note that while in exile the idea of home can become romanticized. The Palestine that the people in the diaspora remember no longer exists as it once did, and is glorified by stories of the past (Schulz \& Hammer, 2003, 98). The symbol of the house key powerfully represents the desire for home in the Palestinian diaspora and refugee population. In 1948, when Palestinians fled from their houses, they kept their house keys planning to return. However, once they found that their houses had been taken over or destroyed they still kept their house keys as a symbol of the return to their homes and to normal life (Sa'di, 2002). For the Palestinian people the house key symbolizes loss and homelessness but also hope for the future. One of the participants in a refugee camp in Beirut during an interview with Miriyam Aouragh expressed her hope to go back to Palestine: "People want to, but don't believe they can, go back to Palestine. 
But we should believe it, because if you cut off the hope of returning to Palestine you're nobody: a person without a homeland is like a person without roots" (Aouragh, 2011, 6).

Theme 3: Transnationalism and Hybridity. Another common theme found in the literature is transnationalism and hybridity in the diaspora. Ibrahim Aoudé (2001) focuses on some of the ways in which Palestinians in the diaspora maintain their culture (i.e. speak Arabic and observe Palestinian Arab customs and traditions) through contacts with one another across continents. Aoudé (2001) looked at his personal friends and relatives and his interconnections with them in three different countries: The United States, Australia and Ecuador. He evaluated their 'Palestinianness' and discussed the ways in which they kept their Palestinian culture and identity. Although this article only includes observations from the author's perspective (he did not interview his friends and relatives, only wrote about them), it is an insightful piece on the everyday lives of Palestinians in the diaspora and how they connect to their friends and family around the world. He concludes that Palestinians in the diaspora struggle with their national and ethnic identity in order to resolve their sense of self (Aoudé, 2001).

Another aspect of transnationalism is recreating home away from home. Schulz and Hammer $(2003,178)$ describe how Palestine is recreated in exile by speaking Arabic, cooking Arabic food and decorating their houses with pictures of the Dome of the Rock and Yasser Arafat, embroidery, Palestinian flags and other cultural and national 'icons'. Also, in order to keep strong Palestinian ties when moving to a new country, new immigrants often make friends through organizations and activities that sympathize with the Palestinian cause (Schulz \& Hammer, 2003, 178). These actions help new immigrants feel closer and always connected to their old home. 
In the book The Palestinian Diaspora: Formations of identities and politics of homeland, Schulz and Hammer $(2003,171)$ say that one of the central aspects of transnational activities is family contacts, and that visiting, sending letters, receiving phone calls, attending weddings and funerals, helping to facilitate migration, and sending remittances are ways of keeping the family together despite the distance. They point out that new information technologies are helping link Palestinians families together in new ways, while arguing that Palestinian families are the most important institution in creating Palestinian identity and community (Schulz \& Hammer, 2003, 172). Because the modern world is in constant movement with free-flowing capital and international migration, it is assumed that transnationalism equals more mobility for all. But for the Palestinian diaspora, immobility and forced mobility are more of a reality than free mobility (Aouragh, 2011, 5). However, in the book entitled Palestine Online:

Transnationalism, the Internet and the Construction of Identity, Miriyam Aouragh (2011, 5) points to the internet as a glimmering hope for Palestinians in exile: "Communities that were traditionally separated by national boundaries and travel restrictions have now found new modes of connection via internet interaction". Aouragh $(2011,105)$ argues that the Internet is not going to save Palestine, but that it will definitely contribute to its liberation. Therefore, transnational communication with family and close friends is crucial for maintaining identity in the diaspora.

In Mason's (2007) case study of Palestinians from Kuwait living in Australia, she found that communication technologies were used by all generations. Many of the people interviewed said that email is the most common way of keeping in touch with their families around the world. They also pointed to the fact that the Internet helps them find 
alternative information about Palestine and the conflict with Israel, enabling feelings of greater solidarity within the diaspora (Mason, 2007). Interestingly, second generation youth have described their relationship with their homeland as 'three-dimensional' and 'virtual', especially compared to their parents' experiences of learning about Palestine through books, songs, and poetry (Mason, 2007). Now, there are Internet blogs from the Palestinian Territories, chat rooms, email groups, and international organizations online that people can participate in and feel more connected to their homeland (Mason, 2007). Mason (2007) also noted that transnational communication among this particular group of Palestinian Australians helped them with their settlement in Australia by making them feel less isolated and closer to the wider Palestinian community.

Along with transnational diasporas, come transnational or hybrid identities. Edward Said used the term hybrid as a representation of Palestinian-ness when he said, "I believe that essentially unconventional, hybrid and fragmentary forms of expression should be used to represent us" (Schulz \& Hammer, 2003, 169). Said believes that what is unique about Palestinians is their constant mobility and ability to define themselves in many different circumstances (Schulz \& Hammer, 2003, 169). Although many Palestinians are living in exile, they have established roots and attachment to the new countries in which they live in, which have contributed to their ideas of identity, home and belonging (Mason, 2007). Mason (2007) uses Bhabba's concept of the hybrid 'third space', meaning the tumultuous space in which cultures meet, to explain how Palestinians in the diaspora understand and negotiate their multiple identities. The 'third space' gives them a place to experience their transnational-ness and combine all of their identities into one hybrid identity. 
Theme 4: Struggle and Resistance. Despite their vulnerability, Palestinians describe themselves as those who resist and fight and those who never give up hope (Schulz \& Hammer, 2003, 118). In the 1960s, with a rise in Palestinian activism and militancy and the formation of the PLO (Palestinian Liberation Organization), the Palestinian identity became that of a 'struggler' (Schulz \& Hammer, 2003, 121). Palestinians worldwide resisted Israeli occupation. They fought against exile, against being defined as refugees, and against assimilation into new host countries (Schulz \& Hammer, 2003, 121). In a study on collective identities of Palestinians and Israelis in the diasporas during the Second Intifada (Palestinian uprising) in 2002, Coleman and Lowe (2007) found that many of the Palestinian participants appeared to remain resilient and adaptive in the face of rising violence and hostility during the Intifada. There are also many political solidarity groups, Palestinian cultural clubs, and activist networks within the diaspora, all pointing to the resilience and strong spirit of the Palestinian people worldwide. This next section will focus on this resistance work with particular attention to Palestinian solidarity activism on campuses and the reactions from other student groups and the administration.

\section{Sub-Section 2: Palestinian Activism and the Silencing Campaign on campus}

The Palestinian solidarity movement in Canada has seen many successes over the past few years, specifically on campus. These accomplishments include the introduction of Israeli Apartheid Week (an annual series of events on campuses highlighting the apartheid nature of the state of Israel) in Toronto in 2005 (Ziadah \& Haneih, 2010, 86). Israeli Apartheid Week (IAW) was created at the University of Toronto as a way to educate and discuss the political issues pertaining to Israel and Palestine and create 
awareness on campus to help students understand the harsh realities that Palestinian people face daily under Israeli occupation. IAW includes speakers, lectures, workshops, film nights, cultural events and demonstrations. The mandate of Israeli Apartheid Week is also to build support for the Boycott, Divestment and Sanctions Movement (BDS) which was initiated by over 170 Palestinian civil society organizations in 2005 to call upon the international community to implement a Boycott, Divestment and Sanctions (BDS) strategy against the state of Israel, similar to the campaigns against Apartheid South Africa ("Silencing Criticism,” 2010). The BDS campaign calls for three demands based on human rights. The first demand is ending the occupation and colonization of all Arab lands and dismantling the wall (Bakan \& Abu-Laban, 2009). The second is recognizing the fundamental rights of the Arab-Palestinian citizens of Israel to full equality and the third is respecting, protecting and promoting the rights of Palestinian refugees to return to their homes and properties as stipulated in UN resolution 194 (Bakan \& Abu-Laban, 2009).

Israeli Apartheid Week is based on the anti-oppression framework and challenges all forms of racism, sexism, homophobia, Islamophobia, and anti-Semitism ("Silencing Criticism," 2010) and it has expanded to sixty different cities around the world (Ziadah \& Haneih, 2010, 86). However, Israeli Apartheid Week, along with other Palestinian solidarity activism events, has been targeted by the Harper Government, university administrations and pro-Israeli groups on campus due to its success in "raising legitimate criticism around Israel's violations of international law, and for expanding public awareness about the severe and long-standing consequences of apartheid on Palestine and Palestinians" (“Silencing Criticism,” 2010). 
In an article written in 1984, Edward Said (as cited by Feldman 2008) asserted that Palestinians did not have "permission to narrate" their own stories or to make their own claims. As Mathew Nelson (2007) echoes, refugees and stateless people are reduced to silenced, 'non-political' identities emptied of all political agency (Nelson, 2007). Being heard and seen by the international world has been a struggle for the Palestinian people, especially after their massive displacement in 1948 (Feldman, 2008). Nadeau and Sears (2010) argue that the lack of Palestinian stories is "a testament to the success of Israeli policies of silencing and erasure".

This next section draws heavily on Nadeau and Sears' articles, The Palestine Test: Countering the Silencing Campaign (2010) and This is What Complicity Looks Like: Palestine and the Silencing Campaign on Campus (2011) which both explain the deterioration of freedom of expression, social justice and academic freedom on North American campuses in the context of silencing campaigns to shut down Palestine solidarity work. The authors argue that the silencing campaign has deep roots in the history of Palestinian 'unfreedom', which has focused on efforts to erase Palestinian existence (Nadeau \& Sears, 2010).

After the Israeli assault on Gaza in December 2008 and January 2009, the silencing campaign intensified in response to mobilizations and solidarity movements (Nadeau \& Sears, 2010). The campaign specifically targeted campus events such as Israeli Apartheid Week (IAW), however, during this time, it was clear that Palestinian organizations and supporters were also being targeted outside of the campus (i.e. The Canadian Arab Foundation was defunded and George Galloway, a British MP and Palestinian supporter was banned from entering Canada) (Nadeau \& Sears, 2010). On campuses in Ontario, the 
silencing campaign included attempts to ban the words "Israeli apartheid" on McMaster campus in 2008, the banning of Israeli Apartheid Week posters on four campuses in 2009, attempts to ban Israeli Apartheid week altogether and condemnation of the event. There have also been efforts to shut down the conference titled "Israel/Palestine: Mapping Models of Statehood and Paths to Peace” at York University in 2009, and attacks in the National Post aimed at an OISE (University of Toronto) graduate student who was writing her thesis on Israeli apartheid (Nadeua \& Sears, 2011).

This silencing campaign relies on the logic that Palestinian existence complicates the narrative of the state of Israel, which is that Israel is a promised land for the Jewish people, who, though once oppressed, have now claimed the right to self-determination in their ancestral home (Nadeau \& Sears, 2010). If the existence of Palestinians is acknowledged, then the state of Israel must deal with issues of forced displacement of an indigenous people and their ongoing occupation and oppression (Nadeau \& Sears, 2010). Therefore, the silencing campaign exists to ensure that Palestinian voices and those who would support them are not heard. The following three themes will outline some of the ways in which the campaign seeks to delegitimize Palestinian activism. First, theme one examines the accusations of Palestinian solidarity activism as anti-Semitic. Theme two focuses on the claims that Palestinian activists are threatening and uncivil. Theme three will conclude with discussing the securitization of Palestinian voices and the implications to academic freedom.

Theme 1: Accusations of Palestinian Solidarity as Anti-Semitic. One way that the silencing campaign stifles voices is by accusing critics of Israeli policies of antiSemitism. The silencing campaign has redefined the term 'anti- Semitism' so that it 
focuses on attitudes towards Israel rather than the human rights of Jewish people (Nadeau \& Sears, 2010). For example, Michael Ignatieff (of the Liberal party of Canada) said that Israeli Apartheid Week "went beyond reasonable criticism into demonization" by supposedly condemning Israel solely on the basis that it is a Jewish state (Nadeau \& Sears, 2010). In addition, B'nai Brith (a pro-Israeli advocacy organization) placed an advertisement in the National Post in 2009 warning Jewish students and friends of Israel that they should "prepare to face hate on campus", grouping together actual attacks on Jewish students with Palestine solidarity activities (Nadeau \& Sears, 2010). The House of Commons put forward a motion stating:

This House considers itself to be a friend of the State of Israel ... [and] is concerned about expressions of anti-Semitism under the guise of "Israeli Apartheid Week"... [and] explicitly condemns any action in Canada as well as internationally that would equate the State of Israel with the rejected and racist policy of apartheid. (Ziadah 2010).

This inclusion of Palestinian activism within a framework of anti-Semitism is an attempt to discredit and delegitimize Palestinian solidarity work by implying that it is a form of anti-Jewish hatred (Nadeau \& Sears, 2010). Nadeau and Sears (2010) also claim that accusations of anti-Semitism are grounded in the denial of Palestinian existence, suggesting that there are no other possible grounds for questioning Israeli policies other than that it is a Jewish country. Ziadah (2010) says that using the term anti-Semitism in this context is nothing but a smear tactic with no factual evident to support it.

Furthermore, in an act to equate Palestinian solidarity work with anti-Semitism, The Canadian Parliamentary Coalition to Combat Anti-Semitism (CPCCA) was formed 
in 2009 describing itself as a "coalition of concerned parliamentarians aiming to confront and combat the global resurgence of Anti-Semitism" ("Silencing Criticism," 2010). The CPCCA has claimed that this "new anti-Semitism" is "especially prevalent on campuses" and has identified universities and academia as an urgent target ("Silencing Criticism," 2010). The CPCCA is comprised of 21 members of Parliament and is directed by Irwin Cotler of the Liberal Party and Jason Kenney of the Conservative Party. Both Kenney and Cotler support the idea that advocating for Palestinian human rights is a new form of anti-Semitism (“Silencing Criticism,” 2010).

Theme 2: Palestinian Solidarity as 'Uncivil' and 'Threatening'. In addition to being accused of anti-Semitism, Palestine solidarity work has also been accused of being uncivil, disrespectful, and a threat to human rights. Again, Michael Ignatieff argued that Israeli Apartheid Week "should be condemned by all who value civil and respectful debate about the tragic conflict in the Middle East" (Nadeau \& Sears, 2010). Nadeau and Sears (2010) point out that it is always Palestinian solidarity activism that is cast in the role of disturber of peace, while Israel advocacy is seen as civil and respectful. In the case at Concordia University in Montreal, Engler (2005) describes the extreme reactions to the anti-Netanyahu (the Prime Minister of Israel) demonstration: "Protesters were accused by media around the world of being anti-Semitic, enemies of free speech, violent anarchists, Arab terrorists, Nazi-like precursors to the new Kristalnacht and more" (Engler, 2005). These accusations were due to a student demonstration and cancelation of a speech by the Prime Minister of Israel.

Nadeau and Sears (2010) label this 'racial Palestinianization,' which frames Palestinians and their supporters as a 'despised and demonic racial group'. This adheres 
to the already widespread anti-Arab and anti-Muslim Islamophobia within Canada and the US since September $11^{\text {th }}, 2001$. Palestinians and Palestinian solidarity work is thought to be cunning, dishonest and a problem that needs to be dealt with (Said, 2007, 47).

Theme 3: Securitization of Palestinian voices and academic freedom. This antiPalestinian rhetoric falls in line with the trend of securitization that the Canadian government is incorporating into its policies. As Russo (2008) and Edwards (2009) point out, the human security paradigm or 'securitization' leads to a labeling of populations as threats to security. Some immigrant groups, especially refugees, are now being portrayed as potential terrorist threats or threats to the fabric of Canada. For example, in the weeks leading up to Israeli Apartheid Week in 2009, four Ontario university administrations banned the Israeli Apartheid Poster (which was a cartoon depiction of a military helicopter labeled "Israel", firing a missile on a child labeled "Gaza") arguing that the poster was 'too violent', 'a threat to safety', 'harmful to civility' and a risk to 'rights and dignity’ (Nadeau \& Sears, 2010). At each university, Palestine solidarity activists were targeted because their actions were seen to be 'equity discrimination' and a violation of 'human rights' (Nadeau \& Sears, 2010). B'nai Brith branded Israeli Apartheid Week as a 'hate fest' and a breeding ground for promoting hatred against Jewish students (Nadeau \& Sears, 2010). Police and university presidents were warned to be on alert for aggressive acts and hostile activity. Nadeau and Sears (2010) argue that, The overamplification of Jewish victimization erases the extreme racisms applied to Arabs, Muslims, and Palestinians in the current racist climate. In essence, then, the "new antisemitism" discourse contributes to an inversion of actual racist 
hierarchies and serves to enforce a racial contract that hides the apartheid-like character of the state of Israel (Nadeau \& Sears, 2010).

Another example of this securitization is the backlash against the conference Israel/Palestine: Mapping Models of Statehood and Paths to Peace, which was cosponsored by York University and Queen's University and took place in June 2009. Mazen Masri (2011) wrote an article about the incident entitled A Tale of Two Conferences: On Power, Identity and Academic Freedom and Jon Thompson (2011) wrote a very detailed book about it entitled No Debate: The Israel Lobby and Free Speech at Canadian Universities. The conference, which was meant to be an open forum for scholarly exchange and debate on the topic of Israel/Palestine, met much criticism and opposition from York University and external interest groups (Masri, 2011). Suggestions were made by the administration such as excluding the Palestinian member of the organizing committee to achieve "better optics" or adding a Zionist to the committee to balance the committee out (Masri, 2011). Contested concepts and language like 'respect', 'professional responsibility' and 'civility' were invoked by the administration, encouraging the conference organizers to engage in 'civil' and 'respectful' debate (Masri, 2011). As Masri (2011) points out, these terms are vague and could be used to restrict academic freedom. In addition to criticism, booked rooms were also mysteriously found cancelled. However, despite all this, the conference did end up successfully taking place in June 2009 (Masri, 2011).

In addition to the regulation of activism on campuses, some universities are able to control dissent through the use of discipline. In Bruneau and Turk's book Disciplining Dissent, Ian Boyko $(2004,169)$ illustrates that universities' Codes of Conduct target 
activists by threatening academic penalty because of non-academic behaviour. Basically, student activism can and has been stifled by threatening students' access to transcripts and university accounts (Boyko, 2004, 169). In Ottawa University's Code of Conduct, prohibited activities include those that "promote hatred, violence, propaganda or are of a political nature designed to disparage a government, state, country, religion, individual or group of people" and those that "harm the university's reputation or place the university in the middle of ethnic or other world conflicts" (Boyko, 2004, 170). Boyko $(2004,170)$ points out that according to the Codes of Conduct, criticizing a government is equated with bigotry and that getting involved in any activity of a 'political nature' is unacceptable. Clearly, university institutions, Jewish and Israeli advocacy groups, and the Government of Canada all consider Palestine solidarity actions to be threatening and assert that they should be controlled and contained, securitizing political dialogue and Palestinian voices on campuses.

As the Palestine Freedom of Expression Campaign (“Silencing Criticism,” 2010) notes, campus activism and events like Israeli Apartheid Week are important instruments in building critical discourse and open dialogue around the contentious issue of Israel and Palestine. Because Zionism and pro-Israeli advocacy is built on the denial of the Palestinian existence and its main goal is to silence the Palestinian experience, Ziadah and Haneih $(2010,92)$ point out that the Palestinian solidarity movement must work twice as hard to bring light to the Palestinian and Palestinian diasporic experience. They reiterate that this means making sure that Palestinians are allowed and encouraged to speak for themselves and that their voices are heard (Ziadah \& Haneih, 2010, 92). It is hoped that this project contributes to the vital work that is bringing the Palestinian 
experience to the forefront and that most importantly Palestinian voices are heard clearly throughout the paper. Although there is ample literature on Palestinian diasporic identities and some emerging literature on diasporic resistance, this MRP links the two and finds connections between identity and political action, filling gaps in the literature. Through a historical understanding of Palestine, an understanding of how identity can be formed and recognizing patterns of Palestinian diasporic identity, we can gain perspective into how Palestinians in Canada negotiate their identity and participate in resistance. 


\section{Section 5:}

\section{Methodology}

The previous sections explored the formation of identity, the history of Palestine, patterns in Palestinian identity in the diaspora and recent trends in the subjugation of Palestinian student voices. The remainder of this research paper will explore how Palestinian university students in Ontario understand their identity and carry out Palestine solidarity activism.

Ravitch and Riggan in their book, Reason \& Rigor, explain Michelle Fine's research on hybrid identities of marginalized youth. They argue that,

If one's research seeks to investigate the influences of power, hegemony, and inequity on identity development with marginalized and oppressed populations, one's research methods must interrupt broad social trends that serve to marginalize the voices of these research participants given the power structures and how they become instantiated and enacted within the research process itself (Ravitch \& Riggan, 2012, 55).

Throughout the research process, I will strive to be sensitive to the possibility of the further marginalization of Palestinian students and will ensure that their voices are heard above mine at all times and to the best of my efforts.

To reiterate, this MRP will focus on how young Palestinians in the diaspora understand their identity, and whether this understanding, as well external perceptions of identity, shape their political actions in terms of solidarity movements with Palestine on Ontario campuses. The question is two-fold: first, how does a Palestinian-Canadian identity impact the political action of a Palestinian-Canadian university student, and how 
do their political actions in turn impact their identity formation and reformation. The second part relates to how those political actions are then perceived by other students, student groups and the university administration on campuses in Ontario. And it relates to how their identities are further affected by potential resistance to Palestinian solidarity actions on Ontario’s campuses.

This section outlines the methodological approach and strategy to this research project. A summary of the sample size and recruitment strategies will also be offered, along with a description of the setting of interviews, the data collection tools used, scope and limitations of the study and the potential ethical risks. Lastly, this section will end with a description of the participants involved.

\section{Approach and Strategy}

I will be using a qualitative approach to this research project. As this study is focusing on identity, using a qualitative approach allows one to explore the subtleties of individual beliefs and the nuances that speaking with respondents can provide (Archer \& Berdahl, 2011).

The strategy that I will be using is phenomenology. As Ravitch and Riggan (2012) state, phenomenology is a branch of philosophy concerned with the nature of phenomena. According to Groenewald (2004), German philosopher, Edmund Husserl is regarded as the fountainhead of phenomenology in the 20th Century as he sought to develop a new philosophical method, which would delegitimize 'absolute certainty'. Husserl rejected the belief that the external world existed independently and that information about it is reliable (Groenewald, 2004). He argued that it is possible that people can be certain about how things appear, but cannot be certain about anything 
outside their immediate experience (Groenewald, 2004). Realities are therefore treated as 'phenomena'.

In psychology, phenomenology holds that a person's experiences cannot be observed objectively, but can only be understood on their own terms within a person's broader interpretation of their experiences in the world (Ravitch \& Riggan, 2012, 111). Because my study focuses on individuals' identity formation and actions impacted by that identity, the phenomenology perspective allows me to focus on individual's meaning making of their identity and their personal experiences.

\section{Sample and Recruitment}

In order to recruit participants, I used social networks such as Facebook and email to reach possible participants. I posted recruitment ads on Palestinian activist group Facebook pages and emailed call outs to the official email addresses of the Palestinian campus groups. The requirements to participate were that they must be a current or past university student between the ages of 18 and 35 involved in a Palestinian human rights campus group, who also self-identified as being Palestinian.

\section{Scope and Limitations of Research Project}

For this research study, the scope is within the resources I had and time constraints I worked under. Because of my connections to Palestinian activist networks in Kitchener-Waterloo and in Toronto, I have participants from the University of Waterloo, Wilfrid Laurier University and Ryerson University with one participant also from the University of Western Ontario. This is not an entirely comprehensive list and the eight participants in the study do not represent all Palestinian student activists in Canada or even in Southern Ontario. Because of the small sample size, it is difficult to draw 
definitive conclusions on the subject matter. This project is meant to be an exploratory study seeking to identify themes in Palestinian-Canadian identities and in experiences of activists and their activism on campus. This paper may also provide the foundation for future avenues of research. Another limitation of the study is that the majority of the participants are male. I had hoped to get an even number of male participants and female participants, however most (75\%) of the people who responded to the call-out were males while only two participants $(25 \%)$ were female.

\section{Setting of interviews}

Interviews were conducted mostly in person in private rooms booked on campus libraries to ensure privacy, safety and neutrality. Three interviews took place over the telephone or Skype. The interviews ranged from 45 minutes to two hours. Before the interview started I provided all the participants with background information on myself and told them about my connection to Palestine and my interest in the subject matter. I believe that this was an important part of the process in order to gain the participant's trust and give them a context as to who I am and my reasons and motivations for conducting this study.

\section{Data Collection Tools}

I used two forms of data collection: an informational questionnaire and semistructured interviews. The questionnaire was used to obtain data such as the participant's age, gender, religion, national identity, etc. Most of the questions were close-ended questions with blank spaces provided for the answers, however I had two likert scale questions and a few open-ended questions. In order to situate the participants' national identity, I had a scale that asks the participants to circle the national identity that they 
most identify with, ranging from Canadian, Canadian-Palestinian, Palestinian-Canadian and Palestinian. The questionnaire also includes some open-ended questions such as, 'what is your motivation for being involved in Palestinian activism?' and 'what kinds of events have you been a part of?' (See Appendix 1 for the Questionnaire).

After the short questionnaire, semi-structured interviews were conducted using open-ended questions and prompts, allowing the participants' answers to guide follow-up questions. A benefit to these interviews is that because it is semi-structured, the interview could go in directions that the participant chooses, although I did have prompts and ideas of where I want the interview to go. Open-ended questions are framed in a way that respondents can state their position without any cueing from the researcher, therefore this ensures that more agency and voice is given to the participant (Archer \& Berdahl, 2011).

\section{Addressing Potential Ethical Risks}

During the research process, a potential risk I identified was that the interview questions and process might bring up traumatic memories of past harassment on campus. Therefore, it was made clear to the participants that they did not have to answer every question and should they wish, they could and were welcome to stop the interview at any time. As a precautionary measure in case participants felt the need to contact counseling services, information on nearby counseling resource centers was provided on the Written Consent and Confidentiality Agreement Form that participants signed at the beginning of the interview.

Due to the controversial nature of the topic, participants were ensured full privacy and confidentiality. Firstly, interviews were conducted in private, neutral locations making sure that no one could hear the conversation. Codes were used instead of names 
on all of the data collection forms and during the writing process, extra caution was taken so as not to include identifying characteristics in the paper. In addition, the researcher's computer where the data was saved was password protected to ensure no one could obtain any information on the participants. Lastly, participants were given a chance to review the paper before it was submitted to ensure that they were comfortable with the level of accuracy and confidentiality.

Table 1: Demographics from Questionnaire

\begin{tabular}{|c|c|c|c|c|c|c|c|c|c|}
\hline & $\begin{array}{l}\text { National } \\
\text { Identity }\end{array}$ & $\mathbf{M} / \mathbf{F}$ & Age & $\begin{array}{l}\text { Birth } \\
\text { place }\end{array}$ & $\begin{array}{c}\text { Age of } \\
\text { arrival } \\
\text { in } \\
\text { Canada }\end{array}$ & $\begin{array}{c}\text { Parents' } \\
\text { birthplace }\end{array}$ & Religion & $\begin{array}{c}\text { Visited } \\
\text { Palestine? }\end{array}$ & $\begin{array}{c}\text { Involvement } \\
\text { in activism }\end{array}$ \\
\hline 1 & $\begin{array}{l}\text { Palestinian } \\
\text { - Canadian }\end{array}$ & $\mathrm{M}$ & 22 & Canada & - & $\begin{array}{c}\text { Jordan } \\
\text { Palestine }\end{array}$ & Muslim & $\begin{array}{l}\text { Has been } \\
\text { to Israel } \\
\text { proper but } \\
\text { not the } \\
\text { West Bank } \\
\text { or Gaza }\end{array}$ & $\begin{array}{c}\text { Fairly } \\
\text { involved }\end{array}$ \\
\hline 2 & Palestinian & $\mathrm{F}$ & 19 & Palestine & 16 & Palestine & Christian & $\begin{array}{l}\text { Lived in } \\
\text { Palestine }\end{array}$ & $\begin{array}{c}\text { Fairly } \\
\text { involved }\end{array}$ \\
\hline 3 & $\begin{array}{l}\text { Palestinian } \\
\text {-Canadian }\end{array}$ & $\mathrm{M}$ & 32 & Kuwait & 13 & Palestine & Muslim & no & $\begin{array}{c}\text { Very } \\
\text { involved }\end{array}$ \\
\hline 4 & $\begin{array}{l}\text { Palestinian } \\
\text {-Canadian }\end{array}$ & $\mathrm{M}$ & 27 & Syria & 10 & $\begin{array}{c}\text { Damascus, } \\
\text { Syria }\end{array}$ & $\begin{array}{c}\text { Born } \\
\text { Muslim, } \\
\text { currently } \\
\text { none }\end{array}$ & no & $\begin{array}{c}\text { Fairly } \\
\text { involved }\end{array}$ \\
\hline 5 & Palestinian & M & 23 & $\begin{array}{c}\text { Saudi } \\
\text { Arabia }\end{array}$ & 5 & $\begin{array}{c}\text { Gaza City, } \\
\text { Palestine }\end{array}$ & Islam & no & $\begin{array}{c}\text { Fairly } \\
\text { involved }\end{array}$ \\
\hline 6 & $\begin{array}{l}\text { Palestinian } \\
\text {-Canadian }\end{array}$ & $\mathrm{M}$ & 21 & Kuwait & 3 & Palestine & Islam & no & $\begin{array}{c}\text { Very } \\
\text { involved }\end{array}$ \\
\hline 7 & $\begin{array}{c}\text { It changes, } \\
\text { but } \\
\text { currently } \\
\text { Palestinian } \\
\end{array}$ & M & 27 & Kuwait & 9 & Iraq & None & yes & $\begin{array}{c}\text { Very } \\
\text { involved }\end{array}$ \\
\hline 8 & Palestinian & $\mathrm{F}$ & 19 & USA & 13 & $\begin{array}{c}\text { Jerusalem, } \\
\text { Palestine/ } \\
\text { Kashmir }\end{array}$ & Muslim & yes & $\begin{array}{c}\text { Very } \\
\text { involved }\end{array}$ \\
\hline
\end{tabular}




\section{Participants}

There were a total of eight participants who were a part of this research study. All eight of these participants are similar yet all clearly have differing identities and life experiences and varying experiences with campus activism. Most participants were born in Arab countries, with three participants born in Kuwait, one in Syria, one in Saudi Arabia and one born in Palestine. Only one participant was born in Canada, with another born in the United States. Out of the eight participants, six in total had at least one or both of their parents born in Palestine. Other participants had parents from Syria, Jordan, Iraq and Kashmir.

Participants were between the ages of 19 and 32 with the average age being 23.75 . With the exception of the one participant who was born in Canada, all other participants arrived in Canada between the ages of 3 and 16. In terms of religious affiliation, most participants identify as Muslim, with two identifying as non-religious and one as Christian.

When provided with a spectrum from Palestinian, Palestinian-Canadian, Canadian-Palestinian and Canadian and asked how they identified themselves, half of the group circled Palestinian-Canadian, while almost half of the group circled Palestinian, with one exception. One participant said that their identity changes, but right now they identify as Palestinian. Half of the participants had been to Palestine and half of them had not. I had wondered if visiting Palestine was a factor in their Palestinian identity, however it seems that of those who identified as only Palestinian, one had in fact grown up in Palestine, two had visited Palestine and one had never been there. 
In terms of universities included in the data, half of the participants were involved in activism on the University of Waterloo campus. I believe I had a higher response from students there because I have previous connections to Students for Palestinian Rights at the University of Waterloo. Being a Ryerson student, I also have connections to the Ryerson group, Students for Justice in Palestine/Students for Palestinian Human Rights and therefore got two volunteers from Ryerson University. In addition, there was one participant from Wilfrid Laurier University and one from the University of Western Ontario. Therefore, the cities Toronto, Waterloo, and London are represented in the data. I had hoped to get participants from York University and from the University of Toronto, however did not receive any responses from them, perhaps because I had no previous connections to those groups. Another possibility could be the reluctance to volunteer for fear of being identified. I say this because someone informed me that they had tried to recruit friends from the University of Toronto, but said that they were reluctant to get involved in the study because they felt they had to be very careful with their identity. This could be one possible reason why it took me some time to find enough participants to volunteer. 


\section{Section 6:}

\section{Findings}

Section 5 outlined the methodological methods and explained how participants were recruited and how data was collected. This section will outline the main research findings based on the questionnaire and semi-structured interviews conducted. The findings will be laid out in four sections, highlighting participants' responses to questions asked. The first sub-section pertains to participants' national identity and their opinions and feelings about Canada and Palestine. The second sub-section relates to participants' transnational ties to Palestine (i.e. how they stay connected to 'home', the language they speak, the dispersal of their family around the world and whether or not they have been to Palestine). The third sub-section will focus on the participants' experiences of activism on campus and will illustrate the negative and positive reactions to their political actions. Lastly, the section will conclude with a portion on the relationship between identity and political action.

\section{National Identity}

All participants in the study demonstrated a strong Palestinian identity, whether or not they had ever been to Palestine and whether or not they or their parents were born in Palestine. When asked how they identified themselves, half of the group said that they identify as Palestinian-Canadian and the other half said they identify as solely Palestinian. In addition to vocalizing their identity, all participants demonstrated markers of Palestinian identity such as knowledge of Palestinian history, speaking Arabic, staying in touch with their relatives in Palestine or other countries through transnational networks, and, of course, taking part in Palestinian solidarity work. 


\section{Palestine: a place of belonging}

When asked what Palestine means to them, all participants answered something about how it is their homeland, the place where their roots are, where they belong, or that it is the place that they primarily identify with. Four participants also mentioned that they are proud to be Palestinian.

One participant said that Palestine is more of an idea than a place to him and that it brings up childhood sentiment and nostalgia and is a connection to the past. Other answers were that this connection brings up a sense of obligation or guilt and that being Palestinian means that they come from a people that have suffered. One participant noted that the meaning of Palestine keeps changing for him:

We grew up thinking it was a paradise and central to our lives. And when I went down and I saw so many issues going on, initially I was shocked. At first I wanted to live there, but when I saw how impractical it was, I was very sad... What Palestine means to me, it keeps changing.

Canada: a place of opportunity and escape from reality

When asked what Canada means to them, there was a vast array of answers, with some participants voicing negative feelings towards Canada and others voicing positive ones. The two most common answers were that Canada was a place that provides a good education and opportunities (three participants), and that Canada is an escape from reality (three participants). Two participants also said that Canada was their home.

Many of the other positive comments addressed Canada's reputation concerning freedom of speech and democracy (especially in comparison to Arab countries), which two participants noted. One participant also commented that although Canada is not a peaceful country, he finds Canadian society and Canadian citizens to be peaceful. Others 
individually said that it is a comfortable society, a nice place, and that Canada gave them respect.

Some of the negative comments about Canada were criticisms of the government and its choices because it strongly supports Israel, which two participants brought up. Another was about Canadian society. This participant found that Canada was a cold society where people are not genuinely open and welcoming. This participant found Canadian society in huge contrast to West Bank society, and preferred the welcoming Palestinian society.

The Nakba: the loss of a homeland

When I asked the participants what the Nakba meant to them, one thing that I noticed is how educated they all were about the history of Palestine and current political events. One participant noted that, "we were all born decades later, but we are very familiar with the history of our country after the year 1948, and that's not the case for a lot of other people from different countries."

When asked what the Nakba meant to them, four participants initially said that it was a historically significant event and that the literal Arabic translation is 'catastrophe'. Two also explained that the Nakba was when Palestinians lost their home and land and became stateless and in search of a home. Another two shared their emotions about the event stating that it is "heartbreaking", "the end of happiness", and that it was a time of “injustice, betrayal and disappointment".

Three respondents also shared the personal affects that the Nakba had on them and their families, stating that it meant that their grandparents had to flee their homes and take refuge in other Arab countries, Gaza or the West Bank. One participant said that, "in 
1948, my father's ancestral village was destroyed and in 1967 they had to flee from Palestine altogether. So it's a significant date personally and historically"

Contrary to the literature and other respondents, one person said that the Nakba is not as significant to them as it is to other Palestinians, and that they do not self-identify with it. Interestingly, one other response was that the Nakba was a time when Palestinians lost respect (by becoming homeless and initiating an era wherein they lacked dignity). The Intifadas: the catalyst for involvement in activism

All but one participant were too young to remember anything significant from the first Intifada, which lasted from 1987 to 1993 . However, the second Intifada from 20002005 was very significant for the participants. Literally, intifada means 'to shake up' in Arabic, and three participants talked about how the First and Second Intifadas showed that Palestinians had the power to take things into their own hands and that it was a time when they fought for themselves and resisted. One believed that they were an uprising for people who had no other option and another said that he felt hugely proud that Palestinians stood up against oppression.

Two participants spoke about the hope that it brought them and recalled being really excited at that time. One mentioned its historical and political significance, pointing out that it was one of the biggest political activism events in the world. In terms of the Intifadas' personal significance for the participants, three of the respondents gave credit to the Second Intifada for helping them understand the situation more, for becoming more aware of what's going on in Palestine and for pushing them to get involved with activism. One participant said that their deep passion for social justice was 
inculcated during that time. One participant said that for him, the second intifada reestablished his identity as Palestinian:

It reestablished my identity as a Palestinian. After a while, when we came to Canada we had lost touch for a while from where we were originally from...In general the 1990s was bad for the Arab world...there was not a single legitimate leader in the Arab world so you had kind of abandoned that region of the world. Who are you going to look to for help? Mabarack? Saddam Hussein? They were all by then 20 or 30 years in power. But then, with the Intifada we reattached you know? Palestine! There is still hope. We're still fighting for what we deserve. We're still fighting to get back what was taken from us.

One participant was living in Palestine during the time of the Second Intifada and recalls the curfews and cuts to water and electricity. At one point, the participant and her family were living for eight days without water or electricity. She relayed the story of when an Israeli soldier offered her a bag of chips, illustrating the anger and resistance that young Palestinians felt during the Second Intifada.

I just threw it away because I saw a little kid tied up and blinded in the jeep and [the soldier] was talking to me as if I didn't see him. I was like, no I see him and I'm not taking your chips, you know what I mean?

\section{Transnationalism and the Connection to Home}

The language of Palestine: Arabic

All participants, except for one, speak Arabic at home to at least one of their parents. Some speak Arabic with their parents and English with their siblings, or speak Arabic to their father and English to their mother. However, all participants have a working understanding of the language, whether they are fluent or not. One participant spoke about his changing relationship with the Arabic language. After September $11^{\text {th }}$, he

recalled an effort to dismiss his Arabic and get rid of it completely, perhaps due to fear of persecution. However, now he says he desires to hold onto it because it is a big part of 
Palestinian culture. He is now proud to say that he can speak Arabic and believes that it is one of the most beautiful languages in the world.

Connecting to family around the world

All eight participants have family dispersed in different countries around the world, while seven participants have at least one family member living in Palestine or Israel Proper. The countries mentioned from the Middle East include, Israel Proper, Palestine, (Gaza Strip and the West Bank), Jordan, Egypt, United Arab Emirates, Saudi Arabia, Syria, Lebanon, Kuwait, Iraq, Oman and Cyprus. Other Western or settler countries mentioned were the United States, Sweden, Australia and the United Kingdom. Some participants also have relatives in India, Kashmir, Italy, Spain, Ecuador and Colombia.

To stay in touch with relatives, half of the participants said that they use Facebook, Skype and email communications. One participant said that even his 85 -yearold grandmother is using Skype and Facebook. Three said that they have been able to visit their relatives in person, or that their relatives have been able to visit Canada. However, five mentioned that it is hard to stay in touch with relatives when they are so distant and expressed regret and sadness that they do not have a closer relationship to their relatives in Palestine or other countries.

I met them once when we all went to Jordan. It's not an easy thing to do by any means and I don't feel like I really have a relationship with them. And that makes me sad for sure. I feel like I'm missing out on a big family there, but it's sort of no choice really.

Palestine: personal experiences and the desire to visit the homeland

During the interview and in the questionnaire, participants were asked whether they had ever been to Palestine, and if they had, how their trip affected them. Three 
participants had been to Palestine and five participants had never been. Of the three participants that have been to Palestine, one had grown up in Ramallah in the West Bank and had moved to Canada just recently for school. One participant visited Palestine during a business trip in Israel for two weeks and another has visited Palestine four times visiting family and working with various human rights organizations.

Two participants had attempted to get into Palestine but due to political instability and border controls were not able to. One tried to get into the West Bank to see Bethlehem, however due to tight security, was not able to get through the checkpoint, although he did visit Jerusalem. Another participant attempted to get into the Gaza Strip to visit his father with the Gaza Freedom March (a humanitarian trip commemorating the year anniversary of the attacks in Gaza) in December 2009 and was turned away in Egypt.

Of the three that have been to Palestine, each person experienced it differently and the visit had distinct effects on each participant. The participant who grew up in Palestine said that she feels extremely privileged to have grown up in Palestine because she feels like she has more world experience, knowledge and maturity because of her experiences. The one who visited Israel/Palestine on a business trip said that he learned about Jewish culture and also how Palestinian identity varies significantly between those with Israeli citizenship, those in Jerusalem, the West Bank, Jordan, Iraq, etc. He expressed a feeling of loss because he was shocked at how miserable the everyday realities of Palestinian life were but also experienced a feeling of belonging while there. The participant who has been to Palestine a number of times told me about the profound experiences that have changed her. Along with many other organizations, she volunteered with the Defense for 
Children International and attended Israeli military courts with lawyers. She saw children with their ankles shackled and in brown jump suits on trial and believes that that intense experience changed her the most. She explains another experience that changed her perspective:

I heard a lot of stories that really put a new perspective on who I was, my identity. I have a close friend there who has been to Jerusalem once because he can't get a permit to go and I went 6 or 7 times because I have an American passport and can do that. I don't know what gave me more right than he did, if anything he should have more right than I. I was hard to see the pain in his eyes when he dropped me off at the Qalandia checkpoint and told me to eat a fish for him in Jaffa... it put a different perspective on the day. It makes you appreciate your ability to go out and see what you can see. I can't imagine being confined to that small of a space in the West Bank for a 26 year old guy who wants to do things and see things and can't. He doesn't have the option.

Upon returning home from her trips, she experienced a lot of frustration at the things that people take for granted and their ignorance. She believes that her trip gave her a renewed focus on her education and she is more focused than she was before. Of the five participants in the group that had not visited Palestine, all wished to go someday and one mentioned dreaming of going every day.

Getting into Palestine through Israel can be very difficult, especially for Arabs and those of Palestinian descent. When reflecting on the differences between those who have visited Palestine and those who have not, place of birth came up as a possible significant factor. Those who have been to Israel and Palestine were born in Canada, the United States of America, Palestine, and Kuwait (visited on a business trip). The others who have not been to Palestine were born in other Arab countries such as Kuwait, Syria, and Saudi Arabia. This could be one factor in the difficulty of getting into Palestine through Israel. 
Staying up to date with news in Palestine: the power of the Internet

All participants were very knowledgeable about the situation in Israel/Palestine and kept up to date with events happening there. Seven participants said that they read the news online, citing sources such as BBC, Jerusalem News, Al Jazeera, Al Arabiya, Russia Today and Press TV. Three also stay up to date by reading blogs such as the Angry Arab, the Electronic Intifada, and the Palestinian Solidarity Project. Other ways to keep up to date that were revealed were going to awareness events (mentioned by one participant), speaking to friends or family in Palestine (mentioned by three participants) and Twitter (mentioned by two participants).

I've recently discovered the power of twitter. I'm really impressed. The recent protests in Ramallah were nowhere to be found on other major news organizations. But on twitter there were up to date pictures. It was absolutely amazing to see what was going on in real time, like my entire twitter feed is full of different Palestinian organizations basically.

Clearly, as the participants have shown, the Internet plays a powerful role in the dissemination of information about the conflict in Israel and Palestine.

\section{Activism on Campus}

Getting involved with Palestinian campus activism

Six of the eight participants got involved with Palestinian campus activism simply after seeing a booth on campus and attending events. However, two of the participants were motivated to join campus activism after significant political events. One participant was inspired to join an activist group on campus after attending protests in London and Toronto for the Gaza Freedom Flotilla that was raided by Israeli soldiers on its journey to Gaza. Another was part of a Palestinian cultural club already on campus, but after the Israeli bombing of Gaza, the club shifted to become more political. 
When I started at University, there was no activism for Palestine on campus at all, because the previous [group] had been de-ratified. In 2008, one of the Palestinians on campus started a [Palestinian] club. Initially the plan was just to maintain Palestinian culture, not to focus on politics, because we were aware of the environment we were dealing with. Our campus was very Zionist. We felt that if we just focused on culture and identity, dabke, kneffeh, stuff like that, we wouldn't get de-ratified. That was our original plan. Then the bombing of Gaza happened in December 2008. When that event happened, I guess we grew so frustrated on our campus, because the Israelis still had their activist group and they started this campaign [saying] "would you like to support our war against terror?" The club shifted and wanted to become more activist based.

Motivations for being involved with campus activism

The group of activists all had varying motivations for getting involved with campus activism. The most common answer from a total of five participants was that they wanted to raise awareness about the Palestinian issue because other students do not know enough or because they are bothered by the ignorance of others on campus. Three participants mentioned the fact that they are Palestinian as a motivating factor in their involvement. Two participants also mentioned the sense of community and social involvement that they received by being a part of campus activist groups. Two other participants' motivations were a sense of responsibility, obligation or guilt to work towards helping Palestine, and another two mentioned their religion as a motivation, noting that in Islam you have a responsibility to stand up for the oppressed.

Reactions to Palestinian Solidarity Activism on Campuses:

When speaking with the student activists about their experiences on campus they expressed how they had experienced both support and opposition. While taking part in and helping to organize events like Israeli Apartheid Week, demonstrations and protests, cultural events, awareness activities, movie nights, speakers, educational seminars, hunger strikes, fundraising events and running booths at campus club days, there were 
various reactions from other students, student groups, professors and the University administration. I have grouped these experiences into positive reactions and negative reactions below.

Table 2: Negative and Positive Reactions to Campus Activism

\begin{tabular}{|l|l|l|l|}
\hline $\begin{array}{l}\text { Negative } \\
\text { Reactions }\end{array}$ & $\begin{array}{l}\text { 1. Opposition from } \\
\text { pro-Zionist/Israel } \\
\text { groups }\end{array}$ & $\begin{array}{l}\text { 2. Administration } \\
\text { control }\end{array}$ & $\begin{array}{l}\text { 3. Student apathy on } \\
\text { campus }\end{array}$ \\
\hline $\begin{array}{l}\text { Positive } \\
\text { Reactions }\end{array}$ & $\begin{array}{l}\text { 1. Solidarity with } \\
\text { other student groups }\end{array}$ & $\begin{array}{l}\text { 2. Support from } \\
\text { Individual } \\
\text { Professors }\end{array}$ & \\
\hline
\end{tabular}

Negative Reactions:

1. Opposition from pro-Zionist/Israeli groups on campus.

A common theme in the data was that all of the Palestinian solidarity activists interviewed experienced opposition from pro-Zionist/Israel groups such as Hillel, the Jewish Students Association, Israel on Campus and the Jewish Defense League. These groups made it very difficult for Palestinian solidarity activists to carry out events as planned by stalking Palestinian groups on Facebook, going to events and distributing Zionist flyers to people as they walked in, labeling events as anti-Semitic, taking over the question periods with provocative and aggressive questions or accusations and interrupting speaking events on campus by yelling or creating scenes. One participant recalled the time that one student called the police during an awareness event where they had pictures of Palestine on display:

During our exhibition during Israeli Apartheid Week, this girl walked in and started crying and she was like "this picture is offensive because it's reminding me of the holocaust". She called the cops and the cops took it down. It was in the [school] newspaper for about a week, this incident. People denied that the Palestinian group had the right to put up those pictures because they claimed that it was offensive. 
We're doing an awareness week and you're tearing the photos down. That's just not right.

Another challenge that Palestinian activists face is that pro-Israel/Zionist groups filing complaints with the University administration in order to try and cancel events, claiming that the Palestinian solidarity events are offensive to them.

\section{Administration controlling Palestinian student activism}

Another common theme in the data was that six participants felt controlled by university administrations. The administrations had cancelled already booked rooms for Palestinian solidarity events, banned posters from campus and refused to advertise for their events. One participant spoke about having to get permission from the administration for one of their demonstrations:

I remember when we were doing our protest, we had to hand in our list of chants and we couldn't go outside of those chants...so things like "free free Palestine," "free free Gaza" were fine. I remember someone yelled once "Zionism is terrorism... or Zionism is racism" and that wasn't on the list and we had to hear about it after from the administration.

Two experienced pressure from the administration regarding the complaints from proZionist groups, and were asked to do something in order to make them stop complaining and resolve the tension.

They made it feel like we were responsible for making that group happy and as long as that group is happy then the administration is happy. As a student organization, we should not have to answer to any other student organization.

Although three participants said they did not face any major obstacles, only minor ones, one participant found participating in Palestinian solidarity activism an extremely frustrating experience because of the obstacles student activists must face from the administration. 
This university is not kind to student activists that they don't like, and is deceptive. They're not even clear about their underhanded policies and whatever. So for somebody in second year who doesn't have a lot of experience with that and nobody sort of warning me about it either, it was very very difficult to navigate. Excruciatingly difficult to navigate. And you feel like they don't want you to do what you're doing ever again, they make it that hard.

\section{Apathy}

One student expressed his frustration at the apathy he found on campus, citing that it was difficult to get other students interested in events about Palestine who were not already involved in some way.

There was a sense that a lot of the things we were doing were a waste of time. You know, we're preaching to the converted. So you'll do an event and you'll bring a speaker who'll talk about what's going on in Palestine. You'll have the Arab community showing up [and] possibly some leftist groups who are already on board. It's really hard to convince someone who's on the fence or who's on the other side to show up to these events. There was a great sense of apathy definitely on the university campus.

\section{Positive Reactions:}

\section{Support from other student groups}

All of the students interviewed felt support and solidarity from leftist political student groups, social justice and humanitarian groups and other ethnic or cultural clubs.

One student remarked that he felt the most solidarity with other oppressed people.

You find solidarity with colonized people, even if they're not Arab. They've [The Black Students Association] have dealt with horrific things and discrimination. You find solidarity amongst the oppressed. We work with them. They work with us. Their cause is our cause.

Even among the general student population, participants felt that there was genuine interest and support in the Palestinian cause, mostly due to the fact that Palestinian solidarity activism is humanitarian in nature, and most students can sympathize with and support social justice groups on campus. 


\section{Support from Professors}

One of the participants also said that he felt supported by certain professors and that some of them encouraged activism on campus and would attend their events.

As you can see from the responses, there were some positive experiences of Palestinian solidarity activism on campus and some negative ones. It should be stated that although these students face many obstacles, their will to continue in activism remains strong. Many of them understand that the Palestine/Israel conflict is a highly contentious issue and they are not naïve to the fact that they will hit barriers. One participant explains that,

Being in Palestinian activism in the first place, you're going to hit walls and you're going to hit stigma and backlashes. You have to be able to handle it to be in it. I think that there are boundaries we have to keep pushing. We can't just sit back because people are saying don't protest. We have to protest more because they say don't protest.

\section{The Relationship between Identity and Political Action}

The Impact of Identity on Political Actions

All participants believe that their identity has impacted their political actions. All eight participants said that one of their reasons for being involved in Palestinian activism is because they themselves are Palestinian. One participant spoke about feeling like he had no other choice but to be politically involved because, "you can't run away from your own identity". Another said that his experiences of oppression have shaped his political actions.

I'm Palestinian. We live under oppression and we've dealt with discrimination at home. My identity as a Palestinian, as an oppressed person, as a person who has dealt with colonialism, it has shaped what I stand for. 
Another said that of course she is interested in all aspects of global humanitarianism and social justice issues in other countries, but that she focuses on Palestinian issues because being Palestinian adds a whole other dimension to it and that she can better understand the issues that she's working on. "In my political science classes I've had to write papers on different issues, but the ones that hit closer to home are the ones that I really invest my efforts in because I can understand it."

Clearly, for these participants, having a strong Palestinian identity impacts their political actions and is a motive for being involved in Palestinian solidarity activism on campus. However, that is not to say that being passionate about Palestinian rights is intrinsic to being Palestinian, but for the participants interviewed, having a Palestinian identity motivated them to be an activist.

The Impact of Political Action on Identity

All except for one participant said that being involved in Palestinian solidarity activism had reinforced their Palestinian identity. One mentioned that being surrounded by others who shared their Palestinian identity strengthened their own identity, while another spoke about the support that others showed for his activism on campus as shedding a light on his identity. One participant mentioned that being a part of Palestinian solidarity activism on campus helped him feel connected to his Palestinian culture in a country where he feels like a minority:

In Syria, I never did anything in Syria that was related to activism for Palestine, but at least as far as identity was concerned I didn't really need to do much to feel a strong sense of Palestinian identity when I'm surrounded by Palestinians in a Palestinian refugee camp. But in Canada, that was more of an issue and I guess participating in activism for the Palestinian cause helps make that bond a little stronger. 
Two participants also noted that being involved in activism has helped them

become more knowledgeable about Palestinian issues, which in turn has helped them feel

closer to their Palestinian identity and more passionate about activism.

I felt embarrassed when people wouldn't mention places or towns or cities or villages in Palestine and I didn't know where they were. On the other hand, I felt really proud when I knew exactly where they were and I knew some history. I loved sharing that. It gives you a good feeling. It definitely changes me and a lot of people for the better.

One participant felt detached from his Palestinian culture growing up in a small

town in Canada, but when he joined the Palestinian activist group on campus, he felt like he was reattaching to his Palestinian roots.

My first year of college I didn't join, I stayed to the crowd I was comfortable with, which was the white crowd. But I started making Arab friends. I never had Arab friends before I went to university. I could say things in Arabic and they could understand it. That was cool enough. Then I started going to the events that [the activist group] was holding. I bought my first Palestinian flag and it felt good. I was bringing some light to a part of myself that had been dormant for quite a while. I met some really good, kind and strong people and I wanted to be in that community.

Therefore, according to my study, for most Palestinian activists, being involved in Palestinian solidarity activism reinforces their Palestinian identity. The exception to this pattern was one participant who said that they didn't feel that their identity was affected by their involvement in activism on campus.

I don't think that it's reinforced my Palestinian identity. Most of the people who were part of [the activist group] were not Palestinian, so I didn't feel attached to a Palestinian identity. I felt like I was working for social justice and humanity and not just for Palestine.

The interconnected relationship between identity and political action

Although there are outliers to this model, for the most part a strong Palestinian identity motivated individuals to political action and activism. Simultaneously, being 
involved in Palestinian political activism reinforced their Palestinian identity. Therefore, identity can motivate political action, while political action can reinforce identity. In addition, when the political action on campus met resistance from students and the administration, that experience equally reinforced their Palestinian identity and in turn their motivation towards activism.

Figure 2.1: The interconnected relationship between identity and political action

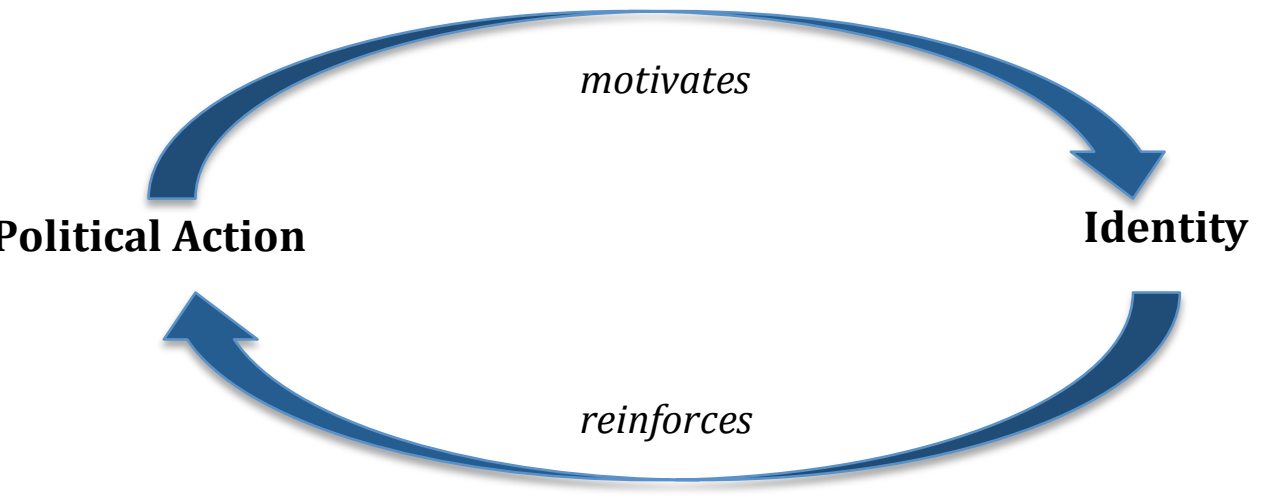

Figure 2.2: The interconnected relationship between identity, political action and resistance to political action

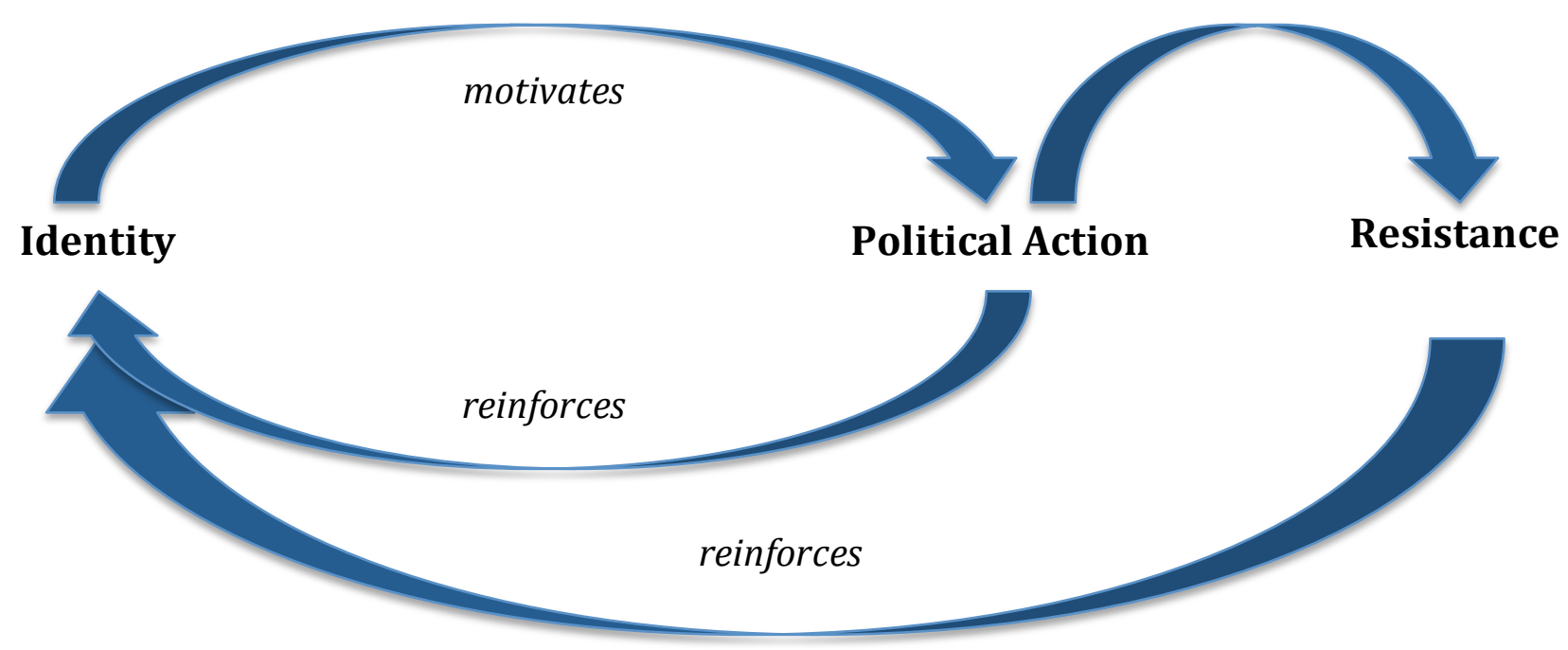




\section{Section 7:}

\section{Analysis and Discussion}

The findings outlined in the last section demonstrate how Palestinian students understand their identity and experience activism on university campuses, while highlighting the interconnected relationship between identity and political action. This next section will analyze various elements of these identities and experiences using theoretical frameworks and existing literature.

Again, the purpose of the study is to find out how young Palestinians in the diaspora in Canada understand their identity and explore how their understanding and how external perceptions shape their political actions in terms of solidarity movements with Palestine. First, I will discuss diasporic Palestinian-Canadian identities using primarily Castells' theory of resistance identity, and then I will use Edward Said's theory of Orientalism to explain the experiences of activism on campuses.

\section{Resistance Identity}

As Castells points out, in a globalized world, the search for a collective or individual identity becomes the fundamental source of social meaning (Bosker-Liwerant, 2002). He highlights resistance identities as those that oppose the dominant group in a globalized society. 'Resistance identity', Castells (2004) argues, leads to the formation of communities and may be the most important type of identity formation in our society. As quoted earlier, "It constructs forms of collective resistance against otherwise unbearable oppression, usually on the basis of identities that were, apparently, clearly defined by history, geography, or biology, making it easier to essentialize the boundaries of resistance" (Castells, 2004, 9). For example, ethnically based nationalism (i.e. Palestinian 
nationalism) arises out of a sense of exclusion, alienation and resentment of the unjust treatment (Castells, 2004, 9). Aouragh $(2011,12)$ reiterates this point by arguing that national identity is particularly strong in non-state 'contested' groups and that as Palestinians are one of the largest and longest lasting stateless and exiled communities in the world, they strongly hold on to their national identity.

This phenomenon is clear in the participants' manifestation of their national identity. Although only one participant was born in Palestine, all participants identify as either Palestinian or a hybrid identity of Palestinian first, then Canadian second. The Palestinian identity as strugglers and resisters can be explained by Castells' (2004) theory of 'resistance identity'. Because the Palestinian people have been oppressed for generations on the basis of their identity (as Palestinians), they have formed types of resistance and defiance against the global powers that dominate them. That defiance has become a marker of identity. Therefore, going along with Castells' $(2004,9)$ theory of 'resistance identity', strong Palestinian nationalism has risen out of a sense of alienation, exclusion and resentment of injustices and has become a tool of survival.

\section{Figure 3: to exist is to resist}

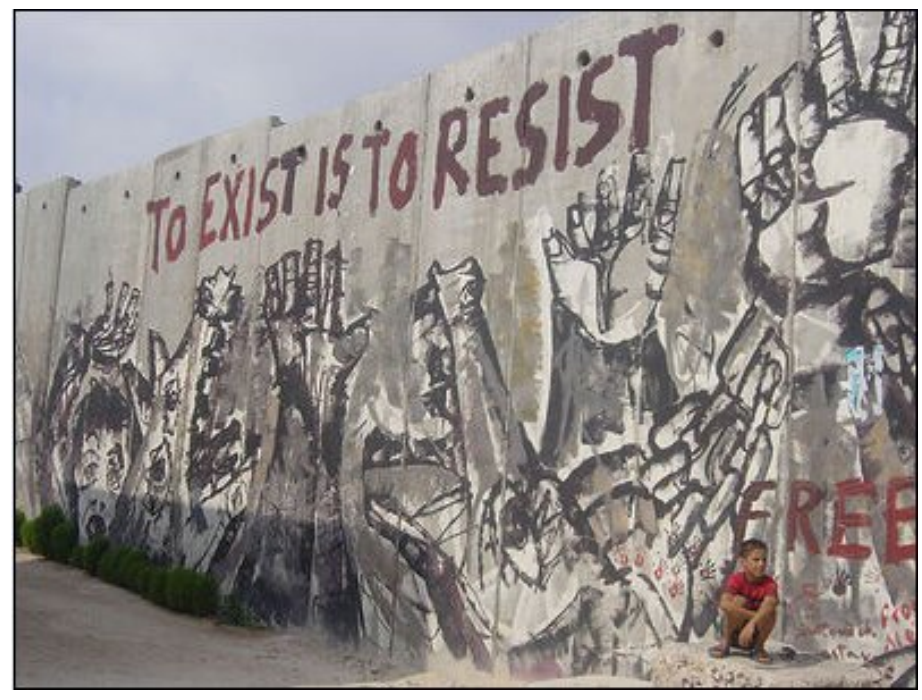

http://the99collective.com/2011/02/to-exist-is-to-resist/ 
On the separation wall in the West Bank in Palestine there is graffiti painted of a Palestinian proverb that says "to exist is to resist". This proverb illustrates the Palestinian struggle and emphasizes resistance identity as the main source of identity formation for Palestinians, pointing out that they have no other choice but to resist. Edward Said (1979, 8) confirms that Palestinian identity is firmly rooted in the act of resistance to foreign Israeli colonialism and that the Palestinian identity must work against a web of racism, cultural stereotypes, political imperialism and dehumanizing ideology.

In Bowker's book about Palestinian refugees $(2003,96)$, he argues that more than any other single factor, the collective memory of the Nakba in 1948 has shaped the identity of the Palestinian refugees as a people. Collective memories do not have to be personally experienced, but they are shared knowledge of past events (Mason, 2007). For example, many people in the Palestinian diaspora were born in other countries and may have never even set foot in Palestine. For these generations, notions of homeland have remained central to ideas of identity. However, their ideas of homeland have been passed on not through lived experience, but through collective memory (Mason, 2007). Most participants in my study spoke about the importance of the Nakba with disappointment and sadness and explained that it was a time when Palestinians lost their home and land, became stateless and in search of a home. The year 1948 marked the beginning of their family living in exile and also marked the beginning of resistance identity for Palestinians. Half of the participants had not been to Palestine and clearly none of them were alive to remember the Nakba, but for them Palestine and the Nakba have remained central to their ideas of identity. 
Eid (2007) describes this strong sense of identity in the diaspora as symbolic ethnicity, which is a lingering ethnic self-concept that is sustained apart from the environment that would reinforce it (i.e. although all but one of the Palestinian students grew up in other Arab countries or in North America, they still felt the strongest affiliation with Palestine). Therefore, those in the Palestinian diaspora have a strong Palestinian identity or symbolic ethnicity, even when apart from Palestine, because of individuals maintaining it themselves. This strong sense of Palestinian national identity could also be rationalized by the lack of belonging that Palestinians feel in other Arab or Western countries. In most host Arab states, Palestinian refugees constitute a noncitizen, marginalized group, becoming 'the other' (Peteet, 2007). This could be one reason why participants born in other Arab countries felt little to no affinity to where they were born and where they spent their childhood. This sentiment is illustrated in a participant's experience of growing up in a refugee camp in Syria:

There is a bit of a sense that you're inferior... at least relative to Syrians... and especially growing up in a refugee camp. [...] I remember in the case of my sister for instance, if people asked her where she was from in Syria, she would try and avoid saying that she lived in a refugee camp. She would try and say something vague like Demascus or make up something. And sometimes for me, I guess I was sort of conflicted. In a way I sort of recognized that people... would see you as inferior because you're Palestinian and because you're from the refugee camp. But sometimes, on some occasions, that almost made me more... you know the opposite sort of reaction where you kind of become overly confident...yeah! like I'm actually from the refugee camp! Take that! I live in the ghetto! [laughs].

For Palestinians, and the participants, the homeland and relation to it constitute a primary aspect of collective identity. One might be from a place but formed by another (Peteet, 2007).

Another point in Palestinian history where the resistance identity of Palestinians was demonstrated was the First and Second Intifadas. The First Intifada between 1987- 
1993 and Second Intifada from 2000-2005 showed that Palestinians are those who resist and fight oppression (Schulz \& Hammer, 2003, 121). The Second Intifada was a very significant time for the participants in this study, marking the beginnings of their interest in activism. For the participants, the Second Intifada showed them that Palestinians had the power to take things into their own hands and resist. Many of them said that they were very proud of this time in Palestinian history remembering the hope that it brought them when they were young. A few participants also spoke about the importance of the Intifada in strongly re-establishing their identity as Palestinian. The Intifadas could be explained by the process that Castells (2004) calls, "the exclusion of the excluders by the excluded." That is, the building of defensive and resistant identities in opposition to dominant oppressive powers, i.e. the Israeli occupation of Palestine.

Lastly, Castell's resistance identity can also illustrate, illuminate and explain the motivating factors for the Palestinian activists to be involved in activism. All participants involved believe that their identity has impacted their political actions and is one of the motivations for being involved. All eight respondents said that one of their reasons for being involved in Palestinian activism is because they themselves are Palestinian. They feel that because of their Palestinian identity they must be involved in Palestinian solidarity activism.

\section{Orientalism}

Edward Said's theory of orientalism is used to explain the reactions to Palestinian campus activism on university campuses by the university institution and other students. As stated previously, orientalist theory relies on binary oppositions: the Orient (the East) is opposite to the Occident (West) (Said, 1978). The Oriental is seen as irrational, 
immoral, or childlike, and 'different'; thus the European is rational, virtuous, mature, and 'normal' (Said, 1978). Orientals, then, were not analyzed as citizens or people, but as problems to be solved or confined or taken over by colonial powers (Said, 2007, 47). As Edward Said (1978) suggests, the Palestinian struggle for freedom is ignored and the occupation of Palestine is justified because the Palestinian population is seen as inferior or 'oriental' (Said, 1978).

Although one participant cited having support from professors and all eight participants mentioned the support from other student groups on campus, they all faced challenges from student groups supporting Israel and university administrations. The university administrations cancelled already booked rooms for Palestinian solidarity events, banned posters from campus and refused to advertise for their events, controlling the capacity and content of events. According to Nadeau and Sears (2010), the silencing of Palestinian solidarity activists has roots in the history of Palestinian 'unfreedom,' which has focused on erasing Palestinian existence. Many participants recalled pro-Israel groups reporting their events and complaining about their events to the administration, claiming that they were offensive and anti-Semitic. One incident involved the police taking a poster down that a pro-Zionist Jewish student claimed to be offensive. This inclusion of Palestinian activism within a framework of anti-Semitism is an attempt to discredit and delegitimize Palestinian solidarity work by implying that it is a form of antiJewish hatred (Nadeau \& Sears, 2010).

Nadeau and Sears (2010) point out that it is always Palestinian solidarity activism that is cast in the role of disturber of peace, while Israel advocacy is seen as civil and respectful. All of these notions of Palestine solidarity work as being uncivil and 
threatening directly tie in to Edward Said's theory of orientalism. Said (1978) argues that through repressive frameworks and politics, Orientals (or Palestinians) are seen as irrational and immoral, whereas Europeans (Israelis) are seen as rational and mature. The silencing campaign on campuses in Ontario is part of this inclination towards the securitization of those who represent different values than those of Canada's; or what Edward Said (1978) would say, the difference between 'us' and 'them'.

One participant noticed the difference in the way that the administration would treat the Jewish Students Association and the Muslim Students Association, noting that the JSA had the privilege of being political, while the MSA did not dare bring politics into their club for fear of being reprimanded by the administration.

The Jewish Students Association have a very weird interest in [our Palestinian activist group] and they champion the Zionist cause full force. By contrast, the Muslim Students Association wants nothing to do with any political issue whatsoever because they're so worried about the administration cracking down on them because they have in the past, so it's harder to get members from that organization even to tell me more about it so I can document it because they are that worried. How come one group has the license to do something....and they won't even advertise for [Palestinian] events.

This difference in treatment is orientalism in practice. The 'other' must be contained, controlled and securitized, while the 'normal' is ration, virtuous and mature. In a world with dominant oppressive powers, the "struggle for recognition" becomes the principal goal of political mobilization (Fraser, 2006, 234). For Palestinian activists, the university campus becomes another battleground in which to fight to be recognized. 


\section{Section 8:}

\section{Conclusion}

This paper has outlined some of the key points in the subject of identity and political action among Palestinian student activists in Canada. Overall, the eight participants had a strong Palestinian identity based on a resistance to dominant oppressive powers and maintained by their connections to their home, the diasporic community and their involvement in Palestinian solidarity activism on campus. The participants' engagement with activism reinforced their Palestinian identity and gave them an avenue in which to work towards social justice in Palestine, maintain their Arabic language, create community and educate others about Palestine. When examining the participants' experiences of activism on campus, they garnered support and solidarity with some student groups and professors, but also faced many barriers and challenges from proIsrael student groups and the university administration. The implications of these findings are significant to the notions of political and academic freedom in Canada and hopefully will encourage universities and Canadian society alike to foster nondiscriminatory political debate and create safe spaces for political activism to ensure that all voices are heard. 


\section{APPENDIX 1}

Questionnaire

Diasporic Identity and Political Action:

Palestinian student activism on Ontario University campuses

Age:

Gender:

Country of birth:

If you weren't born in Canada, at what age were you when you immigrated?

Other countries you have lived in, if any:

Languages spoken:

Religious Affiliation (specify which, or none):

What city do you currently live in?

Where were your parents born?

University:

Year:

Program:

Circle where you would situate your own national identity.

Palestinian - - - Palestinian-Canadian - - - Canadian-Palestinian - - - Canadian

Explain:

How involved are you in Palestinian solidarity groups on campus?

---- very involved ---- fairly involved ---- not very involved ----

Name of Palestinian group affiliated with on your campus:

Years involved with campus group:

Role in campus group (leader, member, etc.): 
What forms or types of actions have you been involved in?

What is your motivation for being involved with campus activism?

Have you visited Palestine? If so, when and with who? (please do not mention names)

What were the personal impacts of your visit to Palestine? How did it affect you?

Did your visit to Palestine affect your motivation to get involved in politics on campus?

If so, how?

If you have not been to Palestine, do you have an interest in going? 


\section{APPENDIX 2}

\section{$\underline{\text { Semi-Structured Interview Questions }}$}

Questions on Identity:

Where were you born? Where did you grow up?

How do you identify yourself? (would you describe yourself as Canadian or Palestinian or a combination of both)

What does the Nakba mean to you?

What does Canada mean to you?

What does Palestine mean to you?

What does the first and second Intifada mean to you? Do you have any experiences of them?

Questions on Transnationalism:

What main language do you speak at home?

Do you have family members dispersed around the world?

How do you keep in touch with them?

Do you have contacts in Palestine? How do you stay up to date with events in Palestine?

Have you visited Palestine? What was your experience like?

Questions on Campus Activism:

How did you get involved with Palestinian Campus Activism?

What types of actions have you been a part of?

What is your general experience of Palestinian activism on campus?

What is your motivation for being involved with campus actions?

How have other campus groups or the University reacted to your events? How have you and your group interacted with other campus organizations? Do you feel as if other groups are in opposition or solidarity with you?

How do you think your identity has impacted your political actions? And how do you think your activism has impacted your identity? Has it reinforced it? Challenged it? Deepened your understanding of resistance? Or not impacted it at all?

Is there anything else you would like to tell me, which I haven't asked? 
Bibliography

Abdelhady, D. (2008). Representing the Homeland: Lebanese Diasporic Notions of Home and Return in a Global Context. Cultural Dynamics 20(1), 53-72.

Agnew, V. (2005). Diaspora, Memory, and Identity: A Search for Home. Toronto, ON: University of Toronto Press.

Allahar, A. (2006). The Social Construction of Primordial Identities. In S.P Hier \& S. B. Bolaria (eds). Identity and Belonging: Rethinking Race and Ethnicity in Canadian Society. (31-42). Toronto: Canadian Scholars' Press Inc.

Al-Rimmawi, H. (2009). Spatial Changes in Palestine: from Colonial Project to an Apartheid System. African and Asian Studies 8, 375-412.

Anderson, W. R. Jr. (2000). Manuel Castells and the Decline of the Twentieth-Century Sociology. The Quarterly Journal of Austrian Economics, Vol. 3(4), 77-89.

Aoudé, I. G. (2001). Maintaining culture, reclaiming identity: Palestinian lives in the diaspora. Asian Studies Review, Vol. 25(2), 153-167.

Aouragh, M. (2011). Palestine Online: Transnationalism, the Internet and the Construction of Identity. London, UK: I.B. Tauris \& Co Ltd.

Archer, K \& Berdahl, L. (2011). Explorations, Second Edition: Conducting Empirical Research in Canadian Political Science. Toronto, ON: Oxford University Press.

Bakan, A. B. \& Abu-Laban, Y. (2009). Palestinian Resistance and International Solidarity: The BDS Campaign. Institute of Race Relations, Vol. 51(1), 29-54.

Bosker-Liwerant, J. (2002). Globalization and Collective Identities. Social Compass, Vol. 49(2), 253-271.

Bowker, R. (2003). Palestinian Refugees: Mythology, Identity, and the Search for Peace. London, UK: Lynne Rienner Publishers, Inc.

Boyko, I. (2004). Students and the Fight for Free Speech in Canada. In W. Bruneau \& J.L. Turk (eds.), Disciplining Dissent: the curbing of free expression in academia and the media. (165-170). Toronto, ON: James Lorimer \& Company Ltd.

Bramadat, P. A. (2001). Shows, Selves, and Solidarity: ethnic identity and cultural spectacles in Canada. Canadian Ethnic Studies 33(3). 78-98.

Castells, M. (2004). The Power of Identity: Second Edition. Oxford, UK: Blackwell Publishing Ltd.

Davis, U. (2003). Apartheid Israel: Possibilities for the Struggle Within. London: Zed Books Ltd.

Edwards, A. (2009). Human Security and the Rights of Refugees: Transcending Territorial and Disciplinary Borders. Michigan Journal of International Law, Vol. 30(3), 763.

Eid, P. (2007). Being Arab: Ethnic and Religious Identity Building among Second Generation Youth in Montreal. Montreal, QC: McGill-Queen's University Press.

Engler, Y. (2005). Playing Left Wing: From Rink Rat to Student Radical. Vancouver, BC: Red Publishing. 
Farsoun, S.K. \& Zacharia, C. E. (1997). Palestine and the Palestinians. Oxford, UK: Westview Press.

Feldman, I. (2008). Refusing Invisibility: Documentation and Memorialization in Palestinian Refugee Claims. Journal of Refugee Studies, Vol. 21.

Fraser, N. (2006). From Redistribution to Recognition? Dilemmas of Justice in a "PostSocialist" Age. In S.P. Sean \& S. Bolaria (eds). Identity and Belonging: Rethinking Race and Ethnicity in Canadian Society. (233-247). Toronto: Canadian Scholars' Press Inc.

Gilroy, P. (2006). Identity, Belonging, and the Critique of Pure Sameness. In S.P. Sean \& S. Bolaria (eds). Identity and Belonging: Rethinking Race and Ethnicity in Canadian Society. (117-126). Toronto: Canadian Scholars' Press Inc.

Groenewald, T. (2004). A Phenomenological Research Design Illustrated. International Journal of Qualitative Methods, Vol. 3(1).

Hall, S. (2006). The Future of Identity. In S.P. Sean \& S. Bolaria (eds). Identity and Belonging: Rethinking Race and Ethnicity in Canadian Society. (250-269). Toronto: Canadian Scholars' Press Inc.

Halper, J. (2009). Obstacles to Peace: A Reframing of the Israeli-Palestinian Conflict. Jerusalem: ICAHD (The Israeli Committee Against Housing Demolitions).

Hammer, J. (2005). Palestinians Born in Exile: Diaspora and the Search for a Homeland. Austin, TX: University of Texas Press.

Hanafi, S. (2009) Spacio-cide: Colonial Politics, invisibility and rezoning in Palestinian territory. Contemporary Arab Affairs, Vol. 2, No. 1, 106-121.

Hasan, Rumy. (2008). The Unitary, Democratic State and the Struggle Against Apartheid in Palestine-Israel. Holy Land Studies.

James, C.E. (2006). Race, Ethnicity and Cultural Identity. In S.P. Sean \& S. Bolaria (eds). Identity and Belonging: Rethinking Race and Ethnicity in Canadian Society. (42-55). Toronto: Canadian Scholars' Press Inc.

Jensen, S.Q. (2011). Othering, identity formation and agency. Qualitative Studies, 2(2), 63-78.

Kalra, V.S., Kaur, R \& Hutnyk, J. (2005). Diaspora \& Hybridity. London, UK: Sage Publications Ltd.

Koyuncu Lorasdağı, B. (2009). The headscarf and 'resistance identity-building': A case study on headscarf-wearing in Amsterdam. Women's Studies International Forum, Vol. 32, 453-462.

Masri, M. (2011). A Tale of Two Conferences: On Power, Identity, and Academic Freedom. Journal of Academic Freedom.

Nadeau, M.J. \& Sears, A. (2010). The Palestine Test: Countering the Silencing Campaign. Studies in Political Economy, Vol. 85.

Nadeau, M.J \& Sears, A. (2011). This is What Complicity Looks Like: Palestine and the Silencing Campaign on Campus. The Bullet: Socialist Project. E-Bulletin No. 475.

Nelson, M. (2007). Taking Political Agency: 'No Border'/'No One is Illegal' Politics in Canada.

Pappe, I. (2006). A History of Modern Palestine: One Land, Two Peoples. Cambridge, UK: Cambridge University Press. 
Peteet, J. (2007). Problematizing a Palestinian Diaspora. International Journal of Middle East Studies 39, 627-646.

Qumsiyah, M.B. (2011). Popular Resistance in Palestine: A History of Hope and Empowerment. New York, NY: Pluto Press.

Ravitch, S.M. \& Riggan, M. (2012). Reason \& Rigor: How Conceptual Frameworks Guide Research. London, UK: SAGE Publications Ltd.

Rockquemore, K.A. (2006). Between Black and White Exploring the "Biracial" Experience. In S.P. Sean \& S. Bolaria (eds). Identity and Belonging: Rethinking Race and Ethnicity in Canadian Society. (147-161). Toronto: Canadian Scholars' Press Inc.

Russo, R. (2008). Security, Securitization and Human Capital: The new wave of Canadian Immigraiton Laws. International Journal of Human and Social Sciences, Vol. 3(4).

Said, E. (1978). Orientalism. New York, NY: Pantheon Books.

Said, E. (1979). The Question of Palestine. New York, NY: Times Books.

Said, Edward. (2002). A Just Peace. In M. Tobin \& R. Tobin (Eds.) How Long O Lord? Christian, Jewish and Muslim Voices from the Ground and Visions for the Future in Israel/Palestine. (239-258). Cambridge: Cowley Publications.

Said, E. (2007). Latent and Manifest Orientalism. In T. Das Gupta (Ed.) Race and Racialization: Essential Readings. (45-55). Toronto, ON: Canadian Scholar's Press Inc.

Silencing Criticism of Israeli Apartheid: A critical report on the Canadian Parliamentary Coalition to Combat Antisemitism (CPCCA). (2010). Palestine Freedom of Expression Campaign Toronto (PFEX).

Schulz, H. L. \& Hammer, J. (2003). The Palestinian Diaspora: Formations of identities and politics of homeland. London, UK: Routledge.

Thompson, J. (2011). No Debate: The Israel lobby and free speech at Canadian Universities. Toronto, ON: James Lorimer \& Company Ltd.

White, B. (2009). Israeli Apartheid: A Beginner's Guide. New York: Pluto Press.

Ziadah, R. (2010). A View From Toronto - A Hub of "Israel Delegitimization". The Bullet Socialist Project. E-bulletin E-322.

Ziadah, R \& Hanieh, A. (2010). Collective Approaches to Activist Knowledge: Experiences of the New Anti-Apartheid Movement in Toronto. In A. Choudry \& D. Kapoor (Eds.). Learning from the Ground Up: Global Perspectives on Social Movements and Knowledge Production. (85-99) New York, NY: Palgrave Macmillan. 